\title{
Quality of life predicts outcome of deep brain stimulation in early Parkinson disease
}

W.M. Michael Schuepbach, MD, Lisa Tonder, MS, Alfons Schnitzler, MD, PhD, Paul Krack, MD, PhD, Joern Rau, Andreas Hartmann, MD, PhD, Thomas D. Hälbig, MD, Fanny Pineau, PhD, Andrea Falk, MD, Laura Paschen, MD, Stephen Paschen, MD, Jens Volkmann, MD, PhD, Haidar S. Dafsari, MD, Michael T. Barbe, MD, PhD, Gereon R. Fink, MD, PhD, Andrea Kühn, MD, Andreas Kupsch, MD, PhD, Gerd-H. Schneider, MD, PhD, Eric Seigneuret, MD, Valerie Fraix, MD, Andrea Kistner, MSc, P. Patrick Chaynes, MD, PhD, Fabienne Ory-Magne, MD, Christine Brefel-Courbon, MD, PhD, Jan Vesper, MD, PhD, Lars Wojtecki, MD, PhD, Stéphane Derrey, MD, David Maltête, MD, PhD, Philippe Damier, MD, PhD, Pascal Derkinderen, MD, PhD, Friederike Sixel-Döring, MD, Claudia Trenkwalder, MD, PhD, Alireza Gharabaghi, MD, PhD, Tobias Wächter, MD, Daniel Weiss, MD, PhD, Marcus O. Pinsker, MD, PhD, Jean-Marie Regis, MD, PhD, Tatiana Witjas, MD, PhD, Stephane Thobois, MD, PhD, Patrick Mertens, MD, PhD, Karina Knudsen, MD, Carmen Schade-Brittinger, Jean-Luc Houeto, MD, PhD, Yves Agid, MD, PhD, Marie Vidailhet, MD, PhD, Lars Timmermann, MD, PhD, and Günther Deuschl, MD, PhD, for the EARLYSTIM study group

Neurology ${ }^{\circledR}$ 2019;92:e1109-e1120. doi:10.1212/WNL.0000000000007037

\section{Abstract}

\section{Objective}

To investigate predictors for improvement of disease-specific quality of life (QOL) after deep brain stimulation (DBS) of the subthalamic nucleus (STN) for Parkinson disease (PD) with early motor complications.

\section{Methods}

We performed a secondary analysis of data from the previously published EARLYSTIM study, a prospective randomized trial comparing STN-DBS $(\mathrm{n}=124)$ to best medical treatment $(\mathrm{n}=127)$ after 2 years follow-up with disease-specific QOL (39-item Parkinson's Disease Questionnaire summary index [PDQ-39-SI]) as the primary endpoint. Linear regression analyses of the baseline characteristics age, disease duration, duration of motor complications, and disease severity measured at baseline with the Unified Parkinson's Disease Rating Scale (UPDRS) (UPDRS-III “off” and "on" medications, UPDRS-IV) were conducted to determine predictors of change in PDQ-39-SI.

\section{Results}

PDQ-39-SI at baseline was correlated to the change in PDQ-39-SI after 24 months in both treatment groups $(p<0.05)$. The higher the baseline score (worse QOL) the larger the improvement in QOL after 24 months. No correlation was found for any of the other baseline characteristics analyzed in either treatment group.

\section{Conclusion}

Impaired QOL as subjectively evaluated by the patient is the most important predictor of benefit in patients with PD and early motor complications, fulfilling objective gold standard inclusion criteria for STN-DBS. Our results prompt systematically including evaluation of disease-specific QOL when selecting patients with PD for STN-DBS.

\author{
Correspondence \\ Dr. Deuschl \\ g.deuschl@ \\ neurologie.uni-kiel.de
}

RELATED ARTICLE

\section{Editorial}

Is outcome of subthalamic nucleus deep brain stimulation in Parkinson disease predictable?

Page 453

\section{Clinicaltrials.gov identifier}

NCT00354133.

\begin{abstract}
From the Département de Neurologie (W.M.M.S., A.H., T.D.H., F.P., Y.A., M.V.), Hôpital Pitié-Salpêtrière, Centre d'Investigation Clinique 1422, Institut du Cerveau et de la Moelle Epinière, Institut National de Santé et en Recherche Médicale, Assistance Publique Hôpitaux de Paris, France; Institute of Neurology (W.M.M.S.), Konolfingen; Department of Neurology (W.M.M.S.), University Hospital Bern and University of Bern, Switzerland; Medtronic (L.T.), Minneapolis, MN; Institute of Clinical Neuroscience \& Medical Psychology and Department of Neurology (A.D., L.W.), Medical Faculty, Heinrich-Heine-University Düsseldorf, Germany, Movement Disorder Unit, Neurology (P.K.), CHU Grenoble Alpes; Grenoble Institut des Neurosciences (P.K., V.F., A. Kistner), University Grenoble Alpes; Inserm U1216 (P.K., V.F., A. Kistner), Grenoble, France; Department of Clinical Neurosciences (Neurology) (P.K.), Faculty of Medicine, University of Geneva, Switzerland; Coordinating Center for clinical trials of the Philipps University of Marburg (J.R., C.S.-B.); Neurochirurgische Klinik im Neurozentrum (A.F., L.P., S.P., J. Volkmann, K.K., G.D.),Christian-Albrechts-Universität Kiel; Neurologische Klinik und Poliklinik (J. Volkmann), Universitätsklinikum Würzburg; Department of Neurology (H.S.D., M.T.B., G.R.F., L.T.), University Hospital Cologne; Research Centre Jülich (G.R.F.); Klinik für Neurologie (T.D.H., A. Kühn, A. Kupsch) and Klinik für Neurochirurgie (G.-H.S.), Campus Virchow, Charité-Universitätsmedizin Berlin; Praxis Kupsch (A. Kupsch), Berlin, Germany; Senvice de Neurochirurgie (E.S.) and Service de Neurologie (V.F.), Hôpital Michallon, Centre Hospitalo-Universitaire, Grenoble; Departments of Neurosurgery (P.P.C.), Neurology (F.O.-M., C.B.-C.), and Clinical Pharmacology (C.B.-C.), University Hospital of Toulouse; ToNIC (F.O.-M., C.B.-C.), Toulouse Neuroimaging Center, University of Toulouse, Inserm, UPS, France; Department of Neurosurgery (J. Vesper), Universitätsklinikum Düsseldorf, Germany; Departments of Neurosurgery (S.D.) and Neurology (D.M.), Rouen University Hospital and University of Rouen; INSERM U1239 (D.M.), Laboratory of Neuronal and Neuroendocrine Differentiation and Communication, Mont-Saint-Aignan; Service de Neurologie (P. Damier, P. Derkinderen), CHU Nantes, Hôpital Laënnec, France; Paracelsus-Elena-Klinik Kassel (F.S.-D., C.T.); Department of Neurosurgery (C.T.), University Medical Center Göttingen; Division of Functional and Restorative Neurosurgery and Centre for Integrative Neuroscience (A.G.), Tübingen; Abteilung für Neurologie (T.W.), Reha-Zentrum Bad Gögging, Passauer Wolf; Department for Neurodegenerative Diseases and Hertie Institute for Clinical Brain Research (D.W.), University of Tübingen; Division of Stereotactic and Functional Neurosurgery (M.O.P.), University Medical Center Freiburg, Germany; Departments of Functional and Stereotactic Neurosurgery and Radiosurgery (I-.M.R.) and Neurology (T.W.), Timone University Hospital, INSERM, Marseille; Institut des Sciences Cognitives Marc Jeannerod (S.T.), CNRS, UMR 5229, Université de Lyon; Centre Expert Parkinson (S.T.), Service de Neurologie C, Hôpital Neurologique Pierre Wertheimer, Hospices Civils de Lyon, Bron; Department of Neurosurgery (P.M.), University Hospital of Neurology and Neurosurgery, Hospices Civils de Lyon, Université de Lyon; Department of Neurology (I.-L.H.), INSERM-1402, Centre Hospitalier Universitaire de Poitiers, University of Poitiers, France; and Universitätsklinikum Giessen und Marburg (L.T.), Marburg Campus, Germany.

Go to Neurology.org/N for full disclosures. Funding information and disclosures deemed relevant by the authors, if any, are provided at the end of the article. The Article Processing Charge was funded by Medtronic.
\end{abstract}

This is an open access article distributed under the terms of the Creative Commons Attribution-NonCommercial-NoDerivatives License 4.0 (CC BY-NC-ND), which permits downloading and sharing the work provided it is properly cited. The work cannot be changed in any way or used commercially without permission from the journal. 


\section{Glossary}

BDI = Beck Depression Inventory; BMT = best medical treatment; DBS = deep brain stimulation; MÅDRS = MontgomeryÅsberg Depression Rating Scale; MDRS = Mattis Dementia Rating Scale; PD = Parkinson disease; PDQ-39-SI = 39-item Parkinson's Disease Questionnaire summary index; QOL = quality of life; STN = subthalamic nucleus; UPDRS = Unified Parkinson's Disease Rating Scale.

High-frequency deep brain stimulation (DBS) of the subthalamic nucleus (STN) is a powerful treatment in selected patients with Parkinson disease (PD) and levodopa-induced motor complications. The benefit of STN-DBS has first been shown in advanced PD with severe motor fluctuations and dyskinesia ${ }^{1-3}$ but more recently, improvement of quality of life (QOL) and motor function have been shown with STN-DBS at an earlier stage. ${ }^{4-6}$ The EARLYSTIM study ${ }^{6}$ addressed STNDBS in patients with PD under 61 years of age who had a good (i.e., $\geq 50 \%$ ) response to levodopa but had had motor complications for up to 3 years (mean $1.5 \pm 0.8 \mathrm{SD}$ years). Intentionally permissive inclusion criteria were chosen that allowed a rather broad population of patients with PD with early motor complications to be included. This was decided to enable recruitment of a large cohort and to build a study population from which one would be able to draw conclusions for a clinical population of a reasonably broad range.

This, however, resulted in a study population of patients with PD with a range from early mild complications to moderately severe and advanced motor complications close to those for the conventional indication for DBS. Therefore, the question came up whether the beneficial effect of DBS in the EARLYSTIM cohort was (mainly or only) driven by a subgroup of the entire population, i.e., the relatively advanced patients. Doubts were uttered by critics of the study whether patients with milder motor complications would benefit from DBS. Indeed, it is possible that the more advanced patients contributed more to the overall beneficial effect of DBS found in the study than patients with very mild and early motor complications.

We therefore performed subgroup analyses to understand the effects of DBS in function of different variables prone to be related to outcome of STN-DBS. In particular, the relative contributions of age, duration of disease, and severity of disease to the effect of DBS on QOL were analyzed.

\section{Methods}

The EARLYSTIM study ${ }^{5,6}$ was a prospective randomized study comparing STN-DBS with best medical treatment (BMT) to BMT alone over 2 years' follow-up with QOL measured with 39-item Parkinson's Disease Questionnaire summary index (PDQ-39-SI) as the primary endpoint. The protocol and statistical plan of the main study are available at nejm.org/doi/suppl/10.1056/NEJMoa1205158/suppl file/nejmoa1205158 protocol.pdf. Hypotheses of predicting factors for outcome were formulated before secondary analyses were carried out. Baseline characteristics, including age, disease duration, duration of motor complications (motor fluctuations and dyskinesia), severity of motor parkinsonian signs "off" and "on" medication as measured with the Unified Parkinson's Disease Rating Scale (UPDRS) motor part (III), severity of motor complications (UPDRS-IV), levodopa response, and baseline QOL (PDQ-39-SI) were expected to contribute to the outcome of QOL. To control for contribution of cognition and mood to the outcome in QOL, the baseline ratings for the Mattis Dementia Rating Scale (MDRS), the Beck Depression Inventory (BDI), and the Montgomery-Åsberg Depression Rating Scale (MÅDRS) were also analyzed as potential predictors for change on QOL. Univariate linear regression analyses of these baseline characteristics vs the change in QOL (PDQ-39-SI) were conducted. $p$ Values $\leq 0.05$ were considered statistically significant and no adjustments were made for multiple comparisons. A multivariate linear regression analysis of the STN-DBS group was then performed including the factors with a $p<0.25$ in the univariate analysis.

A post hoc subgroup analysis was performed for the correlation of baseline PDQ-39-SI with the change in PDQ-39-SI over the 2 years using 4 subgroups of baseline PDQ-39-SI $(<15,15-30,30-45,>45)$.

\section{Data availability statement and protocol standards}

The study protocol and statistical plan is available at nejm.org/doi/suppl/10.1056/NEJMoa1205158/suppl file/nejmoa1205158_protocol.pdf. Data will not be available on the web. Researchers can submit proposals for collaborative studies. The study has been approved by the Kiel and Paris University ethics committees. The trial is registered at ClinicalTrials.gov number, NCT00354133.

\section{Results}

The change in QOL over the 2 years correlated with the baseline value of the PDQ-39-SI in a regression model for each treatment group (STN-DBS $p<0.001$, medical group $p<0.001$ ). However, this effect was more pronounced among patients who were treated with STN-DBS than in patients in the medical control group ( $p=0.0262$ for interaction) (figure 1 ).

If baseline PDQ-39-SI was used to define categories of severity of impairment due to $\mathrm{PD}$, patients with very mild impairment of QOL, i.e., PDQ-39-SI values under 15 , as a group did not benefit from STN-DBS as compared to 
Figure 1 Correlation between 39-item Parkinson's Disease Questionnaire summary index (PDQ-39-SI) at baseline and change to 24 months

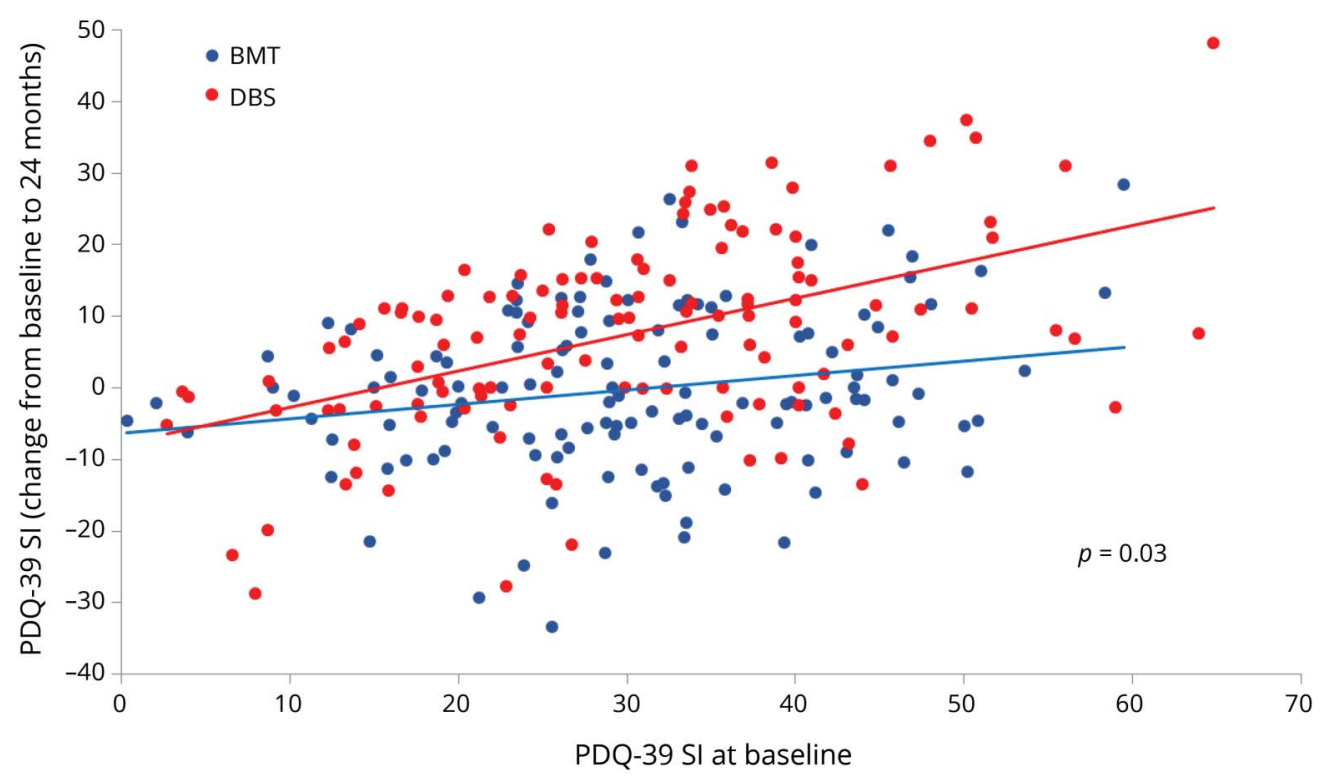

The relation between PDQ-39-SI at baseline and the improvement PDQ-39-SI between baseline and 24 months is shown. The correlation is more pronounced for the deep brain stimulation (DBS) group than for the best medical treatment (BMT) group.

patients in the control group with best medical treatment alone. However, in this group, patients with a very favorable as well as unfavorable outcome in terms of PDQ-39-SI were found. For the other categories with PDQ-39-SI ratings $>15$ at baseline, STN-DBS resulted in better QOL than best medical treatment alone (figure 2). The change from baseline to 5, 12, and 24 months for each patient with a change at each point $(n=241 / 251)$ by treatment group is shown in figure 3.
The change of QOL over the study duration of 2 years was independent of age, duration of PD, and duration of motor complications (motor fluctuations, dyskinesia) at baseline in a regression model. This was the case when analyzed separately by treatment group as well as in a multiple regression model including allocation to the treatment group.

The change of QOL over the 2 years was also independent of the severity of parkinsonian motor signs in the condition

Figure 2 39-Item Parkinson's Disease Questionnaire summary index (PDQ-39-SI) by baseline category

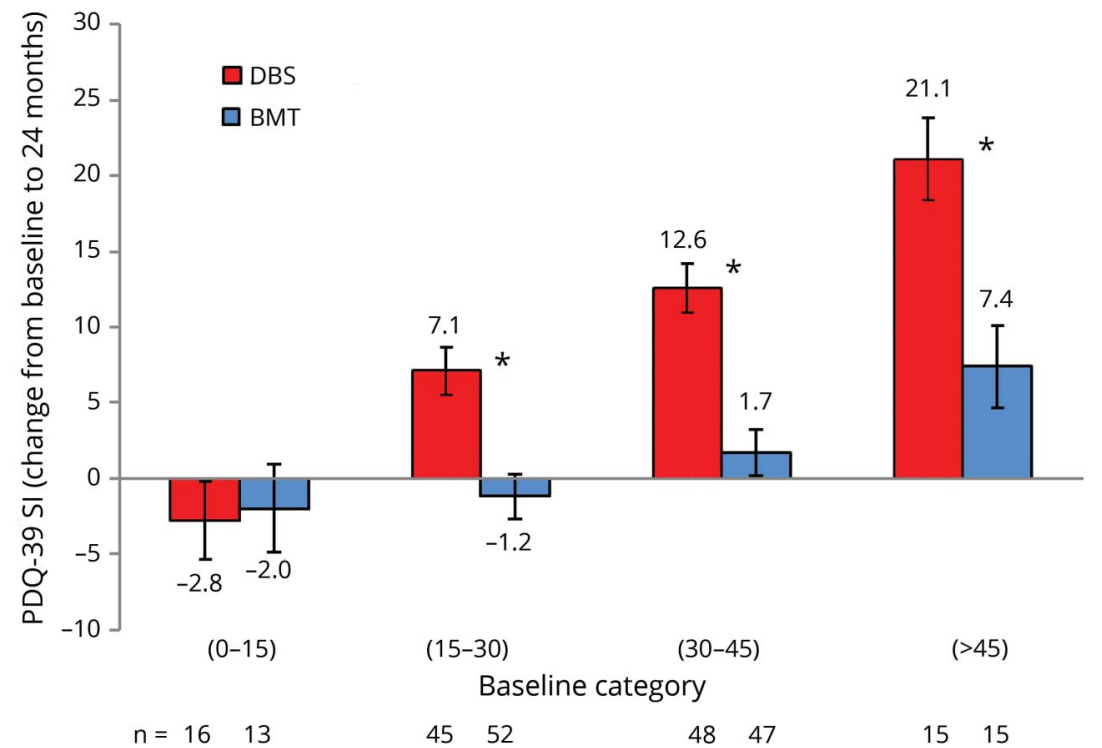

Four categories of PDQ-39-SI baseline values were formed: $0-15,15-30,30-45$, and $>45$ points. Higher values on the PDQ-39 scale mean worse quality of life. The ordinate indicates the change of PDQ-39-SI over the 2 years of the EARLYSTIM study period; negative values mean worsening of quality of life, positive values mean improvement. BMT = best medical treatment (i.e., control group); DBS = deep brain stimulation of the subthalamic nucleus plus best medical treatment; $n=$ number of patients in each group. *DBS vs BMT statistically significant (adjusted model-based $p$ values $<0.05$ ). 


\begin{tabular}{|c|c|c|c|c|c|}
\hline \multirow[t]{4}{*}{ Baseline } & & & & \multicolumn{2}{|c|}{ Change: } \\
\hline & \multirow{3}{*}{ BMT } & B to $5 \mathrm{mo}$ & 1111122112 & \multirow{3}{*}{$\begin{array}{l}0 \\
1\end{array}$} & \multirow{3}{*}{$\begin{array}{l}\leq-15 \\
-15 \text { to } 0\end{array}$} \\
\hline & & B to $12 \mathrm{mo}$ & 0112211222 & & \\
\hline & & B to $24 \mathrm{mo}$ & 1111111222 & & \\
\hline \multirow[t]{7}{*}{$0-15$} & & & & 2 & 0 to 15 \\
\hline & & B to $5 \mathrm{mo}$ & 221111112222222122 & 3 & 15 to 30 \\
\hline & DBS & B to $12 \mathrm{mo}$ & 110111111221222 & 4 & $>30$ \\
\hline & & B to $24 \mathrm{mo}$ & 0011111111112222 & & \\
\hline & & B to $5 \mathrm{mo}$ & 0001101111111222220111222221101111122 & 222 & 22222222332 \\
\hline & BMT & B to $12 \mathrm{mo}$ & 111101111111111111222222220112222222 & 222 & 22222222222 \\
\hline & & B to $24 \mathrm{mo}$ & 000011111111111111111111112222222222 & 222 & 22222222223 \\
\hline \multicolumn{6}{|l|}{$15-30$} \\
\hline & & B to 5 mo & 212231222222312222222222233332222222 & 223 & 3333 \\
\hline & DBS & B to $12 \mathrm{mo}$ & 111112222222211111122222222233333332 & 233 & 3333 \\
\hline & & B to $24 \mathrm{mo}$ & 011111111111122222222222222222222223 & 333 & 3333 \\
\hline & & B to $5 \mathrm{mo}$ & 132000111111191120 & 222 & 3333131 \\
\hline & BMT & B to $12 \mathrm{mo}$ & 1120011111111111112222222211222222233 & 333 & 3331223 \\
\hline & & B to $24 \mathrm{mo}$ & 0001111111111111111111111122222222222 & 222 & 2223333 \\
\hline \multicolumn{6}{|l|}{$30-45$} \\
\hline & & B to $5 \mathrm{mo}$ & 120122233222222223333233333122222333 & 334 & 433333 \\
\hline & DBS & B to $12 \mathrm{mo}$ & 1122222232222222222222333333222223333 & 333 & 344444 \\
\hline & & B to $24 \mathrm{mo}$ & 11111111120 & 333 & 333344 \\
\hline & & B to $5 \mathrm{mo}$ & 112212333321223 & & \\
\hline & BMT & B to $12 \mathrm{mo}$ & 222231222122333 & & \\
\hline & & B to $24 \mathrm{mo}$ & 11111222233333 & & \\
\hline \multicolumn{6}{|l|}{$>45$} \\
\hline & & B to $5 \mathrm{mo}$ & 223333422343444 & & \\
\hline & DBS & B to $12 \mathrm{mo}$ & 22223334234444 & & \\
\hline & & B to $24 \mathrm{mo}$ & 222222233444444 & & \\
\hline
\end{tabular}
baseline show a better improvement.

"off" and "on" medications as measured with the UPDRSIII, and independent of the severity of levodopa-induced complications measured with the UPDRS-IV, as well as "off" time at baseline. This was the case when analyzed separately by treatment group as well as in a multiple regression model including allocation to the treatment group.

The levodopa response of the motor score (UPDRS III) at baseline was not predictive for the change of the QOL outcome between baseline and 24 months in the DBS-group or in the BMT control group.

Cognitive assessment at baseline with the MDRS was not predictive of change in QOL in either treatment group. Self-assessment of mood using the BDI at baseline did not predict change of the PDQ-39-SI after 2 years among patients in the BMT group. However, higher baseline ratings on the $\mathrm{BDI}$ correlated with larger improvement of QOL among patients with STN-DBS. The same was 
observed for mood assessed by the examiner as rated with the MÅDRS in patients with STN-DBS. On the other hand, lower ratings on the MÅDRS correlated with better improvement of the PDQ-39-SI in patients with BMT.

The multivariate regression model in patients with STN-DBS included 4 baseline factors with $p<0.25$ in the univariate analysis: PDQ-39-SI $(p<0.0001)$, BDI $(p<0.001)$, MÅDRS $(p=0.018)$, and UPDRS-III "off" medication $(p=0.216)$. Only the PDQ-39-SI remained significant $(p<0.0001)$ as a baseline predictor for change in $\mathrm{QOL}$ in the multivariate model.

\section{Discussion}

The EARLYSTIM cohort was intended to broadly represent the group of relatively young patients with PD and early motor complications as seen in daily practice. In such a cohort, the potential for improvement may be more modest than in more advanced PD and patients' expectations are high for STN-DBS. Weighing surgery against BMT, knowledge about predictive factors for the improvement of QOL with either treatment is important. Moreover, in view of negative results of STN-DBS in patients with PD before the onset of motor complications, ${ }^{7}$ STN-DBS at a very early stage has been challenged, as the relative contributions of age, disease duration, and duration of presence of motor complications have so far not been disentangled. ${ }^{8}$

QOL at baseline was positively correlated with the improvement of the PDQ-39-SI. This was true for both treatment groups, i.e., patients with worse $\mathrm{QOL}$ at baseline improved more over the 2 years' study period. This was, however, very much more pronounced among patients with STN-DBS than with BMT alone. Baseline impairment of QOL is therefore a reasonable aspect to consider for the decision to treat with STN-DBS. We wondered if there was a floor effect for the benefit from STN-DBS with a minimal PD-related suffering required to have a potential advantage from the intervention. Among patients with PDQ-39-SI ratings under 15 , there was as a group no difference for the outcome in QOL between the treatment groups, and patients with STN-DBS even tended to have worse average outcomes. However, this post hoc secondary analysis must be taken with reserve, especially since the subgroup with PDQ-39-SI ratings under 15 was very small and some individuals in this group had an excellent improvement of QOL with STN-DBS and would wrongly have been barred from a beneficial treatment if a strict cutoff level for the indication of STN-DBS had been applied. In patients with very low baseline ratings on the PDQ-39-SI, the natural progression of impairment of QOL may outweigh the improvement achieved by STN-DBS. On the other hand, some patients with very modest impairment of their QOL seem to have less to gain from STN-DBS. If they choose to undergo neurosurgery, they may do it for the wrong reasons and have expectations that are unrealistic. Therefore they may end up disappointed with the result and show worse ratings on the PDQ-39-SI. Especially thorough assessment of the reasons to undergo neurosurgery and the expectations from STNDBS are therefore needed if the impairment of QOL is very modest. For all other categories with higher PDQ-39-SI at baseline, STN-DBS resulted in improved QOL as compared to best medical treatment alone.

In contrast to the strong prediction of improvement of QOL by baseline PDQ-39-SI ratings, the change of QOL after 2 years is independent from age, disease duration, duration of motor complications, and severity of motor signs and motor complications at baseline. This finding differs from the observation in more advanced $\mathrm{PD}$ in patients with a higher age after 5-6 months where baseline cumulative daily "off" time was a predictor for improvement of the PDQ-39-SI ${ }^{9}$ and younger age was associated with better improvement of the PDQ- $8{ }^{10}$ This difference could be partly related to the longer observation period of 2 years, the different patient profile (younger age, shorter disease duration at surgery) in the EARLYSTIM study, and to a lower variance as a result of the narrower inclusion criteria.

The discrepancy between health-related QOL and motor disease severity at baseline as predictors for the outcome of QOL can be explained by the individual amount of suffering attributed to a given motor impairment. Objective motor improvement does not equal subjective improvement of overall disease-specific QOL. ${ }^{11}$ Moreover, the PDQ-39 not only assesses motor aspects of PD, but affective, behavioral, cognitive, nonmotor, and psychosocial issues are also weighed with this instrument. It is known that motor signs are not the most important determinant of $\mathrm{QOL}$ in patients with PD. ${ }^{12-14}$ Indeed, nonmotor aspects also strongly influence the PDQ-39-SI ${ }^{15}$ and thus contribute decisively to the changes of QOL after STN-DBS. This is likely the reason why the L-dopa response of the UPDRS motor score at baseline is predictive for the motor outcome $\mathrm{e}^{16,17}$ but not necessarily for the QOL outcome after 2 years. ${ }^{9,18,19}$ It has been shown that patients without dementia with borderline preoperative cognitive scores improve less in QOL than those with better cognitive ratings. ${ }^{20}$ However, only patients without dementia without severe depression were included in the EARLYSTIM study. It is therefore not surprising that baseline assessments of cognition (MDRS) and mood (BDI, MÅDRS) were not predictive for outcome. The association of higher ratings on the depression scales with better improvement of QOL among STN-DBS patients may indicate that these patients have a potential for nonmotor improvement to gain from surgery. However, the association was present only in univariate analyses and lost in the multivariate model, in which the PDQ39-SI baseline score dominated all other factors.

An important limitation of our findings regarding generalization is the highly selected patient population. Indeed, the EARLYSTIM cohort consisted of young patients under 61 
with a levodopa response of at least $50 \%$ as an inclusion criterion. STN-DBS has been established as a treatment for motor symptoms in advanced PD. ${ }^{1,21-24}$ Importantly, the response of motor parkinsonian signs to levodopa is an established predictor of the motor outcome of STN-DBS. ${ }^{16,25}$ Parkinsonism that does not respond to L-dopa will not benefit from STN-DBS. ${ }^{26}$ In other words, it is not the severity of the motor signs that predicts motor outcome, but their response to L-dopa. In the present study, levodopa response at baseline was not a predictor of improvement in QOL. Part of the explanation may be related to the fact that the same objective motor sign will not lead to the same subjective suffering, and in the same way improvement of motor symptoms that do not bother a patient will not lead to improvement in QOL, which by definition is subjective. A ceiling effect may also partly explain that no such association was found among our patients with STN-DBS, given the fact that levodopa response of at least 50\% was defined as an inclusion criterion and that the operated patients in the EARLYSTIM study had an excellent average baseline levodopa response of $63.5 \% \pm 16.2 \%$. Therefore, poor QOL in patients with $\mathrm{PD}$ in the absence of L-dopa-responsive motor symptoms should not be regarded as an indication for surgery.

The relation between age, disease duration, and outcome may be different in older patients and in patients with a less pronounced response to levodopa. Better outcome of STN-DBS has been suggested among younger patients with shorter disease duration, $^{25}$ and outcome among older patients has been reported as unfavorable. ${ }^{27}$ However, these patients were operated at a later stage for severe advanced PD. Our data cannot answer the question whether STN-DBS at an earlier stage will remain advantageous over BMT beyond the 2 years of the duration of the EARLYSTIM study. Uncontrolled open long-term observations on patients with STN-DBS, however, show benefits that last up to a decade. ${ }^{28}$

The lack of correlations of age, disease duration, and disease severity with the change of QOL after STN-DBS leaves only baseline ratings of the PDQ-39-SI as a predictor for change of QOL. All patient groups above 15 points of PDQ-39-SI at baseline have on average a clinically meaningful improvement of their QOL (figure 2), which has been estimated to be $\geq 1.6$ points. ${ }^{29}$ The majority of these patients is in the range of PDQ39-SI >15 $(\mathrm{n}=114)$. We therefore consider it very unlikely that the overall favorable outcome of STN-DBS in the EARLYSTIM study has been driven by only a subgroup of patients corresponding to the traditional indication with severe longstanding advanced complicated PD. The major and decisive explanation of the improvement of QOL comes from STNDBS, i.e., the treatment itself across a broad range of patient age and clinical profiles within the EARLYSTIM inclusion criteria.

STN-DBS improves QOL in patients with PD and early motor complications who fulfil the EARLYSTIM inclusion criteria independently of age, disease duration, and disease severity. The subjective individual suffering as measured with the PDQ-39-SI should be taken into account as a predictive factor for outcome when selecting patients with early motor complications for STN-DBS.

\section{Acknowledgment}

Fredy Pene (Hospital Pitié-Salpêtrière, Paris, France; CRA): led and coordinated communication among sites, data review and site compliance check. Anne Bissery (Hospital Pitié-Salpêtrière, Paris, France; project manager): led and coordinated communication among sites, data review and site compliance check. Didier Bouton, $\mathrm{PhD}$ (Department of Clinical Research and Development, Paris, France; project manager): led and coordinated communication among sites, general supervision of study flow. Mathieu Quintin (Department of Clinical Research and Development, Paris, France; project manager): led and coordinated communication among sites, general supervision of study flow. Kerstin Balthasar (Coordinating Center for Clinical Trials, Philipps University Marburg; CRA): led and coordinated communication among sites, data review and site compliance check. Elfriede Stubbs (Department of Neurology, University Hospital, Cologne, Germany; study nurse): administrative assistance and data management in the center. Mandy Schickor (Department of Neurology, Charité-University Berlin, Germany; study nurse): administrative assistance and data management in the center. Susanne Harnisch (Coordinating Center for Clinical Trials, Philipps University Marburg; project manager): led and coordinated communication among sites, general supervision of study flow. Behnaz Aminossadati (Coordinating Center for Clinical Trials, Philipps University Marburg; data management assistance): data review and plausibility checks. Valerie Stoker (Medtronic Neurological, Minneapolis, MN; project manager): led and coordinated communication among coordinators, general supervision of study flow.

\section{Study funding}

This study was funded by grants from the German Ministry of Research (Klinische Studien 01KG0502) and the French Programme Hospitalier de Recherche Clinique National (P050909) and by Medtronic.

\section{Disclosure}

W. Schuepbach is a consultant for Medtronic, Boston Scientific, and Aleva; has served on advisory boards for Ipsen and Merz Pharma; received speaker's honoraria from Allergan and Boston Scientific; and has received unrestricted research grants from Actelion, Boston Scientific, and Medtronic. L. Tonder is employed by Medtronic Inc. A. Schnitzler has received lecture fees from Abbott/SJM, Boston Scientific, Medtronic, and AbbVie and has been serving as a consultant for Abbott/SJM; and is a government employee and receives through his institution funding for his research from the German Research Council, the German Ministry of Education and Research. P. Krack received grants and personal fees from Medtronic, Boston Scientific, and UCB, and grants from St Jude Medical France, Edmond J \& Lily Safra Foundation, French Ministry of Health (PHRC), 
INSERM (French National Institute of Health and Research in Medicine), France Parkinson, Swiss National Science Foundation, Roger De Spoelberch Foundation, Centre National Recherche Scientifique, Orkyn, Homeperf, and Bertarelli Foundation. J. Rau, A. Hartmann, T. Hälbig, and F. Pineau report no disclosures relevant to the manuscript. A. Falk has received lecture fees from Medtronic. L. Paschen has received lecture fees from Medtronic. S. Paschen has received lecture fees from Medtronic, travel grants from Desitin, and travel and educational grants from AbbVie and Boston Scientific. J. Volkmann reports grants and personal fees from Medtronic, grants and personal fees from Boston Scientific, and personal fees from St. Jude. H. Dafsari received grants from the Thiemann Foundation, the Koeln Fortune Program, and the Felgenhauer Foundation and honoraria from Boston Scientific and Medtronic. M. Barbe received speakers honoraria from Medtronic, GE Medical, UCB, and St. Jude and research funding from Medtronic and Boston Scientific. G. Fink serves as an editorial board member of several journals and receives royalties from Thieme and Springer and speaking honoraria from Bayer, Desitin, Forum für medizinische Fortbildung $\mathrm{GmbH}$, and Novartis. A. Kühn has received lecture fees from Boston Scientific, Medtronic, and Abbott and has been serving as a consultant for Boston Scientific; is a government employee; and receives through her institution funding for her research from the German Research Council and the German Ministry of Education and Research. A. Kupsch reports consultancy from Medtronic and speaking honoraria from Allergan, Boehringer Ingelheim, Ipsen Pharma, Medtronic, Merck, Merz Pharmaceuticals, St. Jude, and UCB; and received grants from the German Research Council, German Ministry of Education and Research, and the German Parkinson Foundation. G. Schneider has received lecture fees from Medtronic and travel grants from Abbott and Boston Scientific. E. Seigneuret reports no disclosures relevant to the manuscript. V. Fraix received honoraria from AbbVie France as a scientific consultant. A. Kistner and P. Chaynes report no disclosures relevant to the manuscript. F. Ory-Magne reports serving as advisory board member for Aguettant, AbbVie, and Orkyn; and received travel grants from AbbVie, Orkyn, Homeperf, Aguettant, Actelion, and Merz. C. Brefel-Courbon reports grants from CHU de Toulouse, France-Parkinson Association, and Programme Hospitalier de Recherche Clinique, and has been serving as advisory board member for Zambon and as a consult for Teva, UCB, Aguettant, AbbVie, and Orkyn. J. Vesper reports receiving consulting fees from Abbott, Boston Scientific, and ATI; and received research grants from Abbott and MDT and travel grants from Abbott and Boston Scientific. L. Wojtecki reports receiving consulting fees and lecture fees from Medtronic. S. Derrey and D. Maltête report no disclosures relevant to the manuscript. P. Damier received honoraria from serving on the scientific advisory board of Catapult (UK) and from Novartis and Teva for conferences; and holds some stock options from B\&A Therapeutics (France). P. Derkinderen serves as an associate editor for Frontiers in Neurodegeneration and has received research support from France Parkinson and the Michael J. Fox Foundation for Parkinson's Research. F. Sixel-Döring has received honoraria for lectures and educational activities from AbbVie, Desitin, Grünenthal, Licher MT, Medtronic, $\mathrm{UCB}$, Weser GmbH, Asklepios Kliniken, Klinikum Bad Hersfeld, Klinikum Darmstadt, Conventus Congressmanagement, and Suazio; congress participation and travel costs were sponsored by AbbVie and Licher MT. C. Trenkwalder received grants from the Michael J. Fox Foundation and the European Commission, Horizon 2020, "Propag-ageing," Mundipharma, and UCB; funding for consultancy from Novartis, Benevolent, Grünenthal, Britannia, and Vifor; and speakers fee from UCB, Grünenthal, AbbVie, and Britannia. A. Gharabaghi is funded by the German Federal Ministry of Education and Research (BMBF 13GW0119B and BMBF 13GW0214B) and the BadenWuerttemberg Foundation (NEU005) and receives research support from Medtronic, Boston Scientific, and Abbott. T. Wächter received speaker honoraria from Bial-Portela \& Ca SA and UCB Pharma GmbH. D. Weiss is supported by the German Research Foundation (DFG, WE5375/1-3) and receives research support, speakers honoraria, and travel grants from Medtronic, Boston Scientific, and Abbott. M. Pinsker received speaker fees from Medtronic. J. Régis has received honoraria from Medtronic and a research grant from Elekta. T. Witjas has received honoraria from UCB, AbbVie, Teva, and Medtronic and has received a research grant from the French Ministry of Health. S. Thobois reports grants from Fondation pour la Recherche Médicale and Fondation Neurodis; grants from France Parkinson; personal fees from UCB, Novartis, Teva, St Jude, and Aguettant; and travel and congress grants from Zambon and AbbVie. P. Mertens reports consultancy for Medtronic. K. Knudsen and C. Schade-Brittinger report no disclosures relevant to the manuscript. J. Houeto has received research grant from Agence National de la Recherche, Association France Parkinson, and AbbVie and fees for lectures and consultancies from Medtronic, Zambon, AbbVie, and Lundbeck. Y. Agid receives funds from Servier and the Institut du Cerveau et de la Moelle Épinière. M. Vidailhet reports no disclosures relevant to the manuscript. L. Timmerman received funds from Medtronic, Boston Scientific, Sapiens, St Jude Medical, Bayer Healthcare, UCB, and Archimedes Pharma; grants from M\&U Müller Foundation, NBIA Foundation, and German Parkinson Foundation; and payments for lectures from TEVA, Lundbeck, Bracco, Gianni PR, Medas, UCB, Desitin, Boehringer, GSK, Eumecom, and Orion Pharm. G. Deuschl received lecture fees from Boston Scientific and has been serving as a consultant for Boston Scientific; received royalties from Thieme; is a government employee; and receives through his institution funding for his research from the German Research Council, the German Ministry of Education and Research, and Medtronic. Go to Neurology.org/N for full disclosures.

\section{Publication history}

Received by Neurology May 10, 2018. Accepted in final form November 4, 2018. 
Appendix 1 Authors

\begin{tabular}{|c|c|c|c|}
\hline Name & Location & Role & Contribution \\
\hline $\begin{array}{l}\text { W.M. Michael } \\
\text { Schuepbach, } \\
\text { MD }\end{array}$ & $\begin{array}{l}\text { Assistance Publique Hôpitaux } \\
\text { de Paris, Institut National de } \\
\text { Santé et en Recherche Médicale, } \\
\text { Institut du Cerveau et de la } \\
\text { Moelle Epinière, Centre } \\
\text { d'Investigation Clinique 1422, } \\
\text { Département de Neurologie, } \\
\text { Hôpital Pitié-Salpêtrière, Paris, } \\
\text { France; Institute of Neurology, } \\
\text { Konolfingen, Switzerland; } \\
\text { Department of Neurology, } \\
\text { University Hospital Bern and } \\
\text { University of Bern, Switzerland }\end{array}$ & Author & $\begin{array}{l}\text { Designed and } \\
\text { conceptualized } \\
\text { study, major role in } \\
\text { the acquisition of } \\
\text { data, drafted the } \\
\text { first version of the } \\
\text { manuscript }\end{array}$ \\
\hline Lisa Tonder & Medtronic, Minneapolis, MN & Author & $\begin{array}{l}\text { Analysis or } \\
\text { interpretation of the } \\
\text { data }\end{array}$ \\
\hline $\begin{array}{l}\text { Alfons } \\
\text { Schnitzler, } \\
\text { MD, PhD }\end{array}$ & $\begin{array}{l}\text { Institute of Clinical } \\
\text { Neuroscience \& Medical } \\
\text { Psychology and Department of } \\
\text { Neurology, Medical Faculty, } \\
\text { Heinrich-Heine-University } \\
\text { Düsseldorf, Germany }\end{array}$ & Author & $\begin{array}{l}\text { Designed and } \\
\text { conceptualized } \\
\text { study, major role in } \\
\text { the acquisition of } \\
\text { data, drafted the } \\
\text { manuscript for } \\
\text { intellectual content }\end{array}$ \\
\hline $\begin{array}{l}\text { Paul Krack, } \\
\text { MD, PhD }\end{array}$ & $\begin{array}{l}\text { Movement Disorder Unit, } \\
\text { Neurology, CHU Grenoble Alpes; } \\
\text { Université de Grenoble Alpes, } \\
\text { Grenoble Institut des } \\
\text { Neurosciences, GIN, and } \\
\text { Inserm, U1216, France; } \\
\text { Department of Clinical } \\
\text { Neurosciences (Neurology), } \\
\text { Faculty of Medicine, University } \\
\text { of Geneva, Switzerland }\end{array}$ & Author & $\begin{array}{l}\text { Designed and } \\
\text { conceptualized } \\
\text { study, major role in } \\
\text { the acquisition of } \\
\text { data, drafted the } \\
\text { manuscript for } \\
\text { intellectual content }\end{array}$ \\
\hline Joern Rau & $\begin{array}{l}\text { Coordinating Center for clinical } \\
\text { trials of the Philipps University } \\
\text { of Marburg, Germany }\end{array}$ & Author & $\begin{array}{l}\text { Designed and } \\
\text { conceptualized } \\
\text { study, analysis or } \\
\text { interpretation of the } \\
\text { data, drafted the } \\
\text { manuscript for } \\
\text { intellectual content }\end{array}$ \\
\hline $\begin{array}{l}\text { Andreas } \\
\text { Hartmann, } \\
\text { MD, PhD }\end{array}$ & $\begin{array}{l}\text { Assistance Publique Hôpitaux } \\
\text { de Paris, Institut National de } \\
\text { Santé et en Recherche Médicale, } \\
\text { Institut du Cerveau et de la } \\
\text { Moelle Epinière, Centre } \\
\text { d'Investigation Clinique 1422, } \\
\text { Département de Neurologie, } \\
\text { Hôpital Pitié-Salpêtrière, Paris, } \\
\text { France }\end{array}$ & Author & $\begin{array}{l}\text { Major role in the } \\
\text { acquisition of data }\end{array}$ \\
\hline $\begin{array}{l}\text { Thomas D. } \\
\text { Hälbig, MD }\end{array}$ & $\begin{array}{l}\text { Assistance Publique Hôpitaux } \\
\text { de Paris, Institut National de } \\
\text { Santé et en Recherche Médicale, } \\
\text { Institut du Cerveau et de la } \\
\text { Moelle Epinière, Centre } \\
\text { d'Investigation Clinique 1422, } \\
\text { Département de Neurologie, } \\
\text { Hôpital Pitié-Salpêtrière, Paris, } \\
\text { France; Klinik für Neurologie, } \\
\text { Campus Virchow, } \\
\text { Charité-Universitätsmedizin } \\
\text { Berlin, Germany }\end{array}$ & Author & $\begin{array}{l}\text { Major role in the } \\
\text { acquisition of data }\end{array}$ \\
\hline $\begin{array}{l}\text { Fanny Pineau, } \\
\text { PhD }\end{array}$ & $\begin{array}{l}\text { Assistance Publique Hôpitaux } \\
\text { de Paris, Institut National de } \\
\text { Santé et en Recherche Médicale, } \\
\text { Institut du Cerveau et de la } \\
\text { Moelle Epinière, Centre } \\
\text { d'Investigation Clinique 1422, } \\
\text { Département de Neurologie, } \\
\text { Hôpital Pitié-Salpêtrière, Paris, } \\
\text { France }\end{array}$ & Author & $\begin{array}{l}\text { Major role in the } \\
\text { acquisition of data }\end{array}$ \\
\hline $\begin{array}{l}\text { Andrea Falk, } \\
\text { MD }\end{array}$ & $\begin{array}{l}\text { Neurochirurgische Klinik im } \\
\text { Neurozentrum, Christian- } \\
\text { Albrechts-Universität Kiel, } \\
\text { Germany }\end{array}$ & Author & $\begin{array}{l}\text { Major role in the } \\
\text { acquisition of data }\end{array}$ \\
\hline
\end{tabular}

Appendix 1 (continued)

\begin{tabular}{|c|c|c|c|}
\hline Name & Location & Role & Contribution \\
\hline $\begin{array}{l}\text { Laura } \\
\text { Paschen, MD }\end{array}$ & $\begin{array}{l}\text { Neurologische Klinik im } \\
\text { Neurozentrum, Christian- } \\
\text { Albrechts-Universität Kiel, } \\
\text { Germany }\end{array}$ & Author & $\begin{array}{l}\text { Major role in the } \\
\text { acquisition of data }\end{array}$ \\
\hline $\begin{array}{l}\text { Stephen } \\
\text { Paschen, MD }\end{array}$ & $\begin{array}{l}\text { Neurologische Klinik im } \\
\text { Neurozentrum, Christian- } \\
\text { Albrechts-Universität Kiel, } \\
\text { Germany }\end{array}$ & Author & $\begin{array}{l}\text { Major role in the } \\
\text { acquisition of data }\end{array}$ \\
\hline $\begin{array}{l}\text { Jens } \\
\text { Volkmann, } \\
\text { MD, PhD }\end{array}$ & $\begin{array}{l}\text { Neurologische Klinik im } \\
\text { Neurozentrum, Christian- } \\
\text { Albrechts-Universität Kiel; } \\
\text { Neurologische Klinik und } \\
\text { Poliklinik, Universitätsklinikum } \\
\text { Würzburg, Germany }\end{array}$ & Author & $\begin{array}{l}\text { Major role in the } \\
\text { acquisition of data }\end{array}$ \\
\hline $\begin{array}{l}\text { Haidar S. } \\
\text { Dafsari, MD }\end{array}$ & $\begin{array}{l}\text { Department of Neurology, } \\
\text { University Hospital Cologne, } \\
\text { Germany }\end{array}$ & Author & $\begin{array}{l}\text { Major role in the } \\
\text { acquisition of data }\end{array}$ \\
\hline $\begin{array}{l}\text { Michael T. } \\
\text { Barbe, MD, } \\
\text { PhD }\end{array}$ & $\begin{array}{l}\text { Department of Neurology, } \\
\text { University Hospital Cologne, } \\
\text { Germany }\end{array}$ & Author & $\begin{array}{l}\text { Major role in the } \\
\text { acquisition of data }\end{array}$ \\
\hline $\begin{array}{l}\text { Gereon R. } \\
\text { Fink, MD, PhD }\end{array}$ & $\begin{array}{l}\text { Department of Neurology, } \\
\text { University Hospital Cologne; } \\
\text { Research Centre Jülich, INM-3, } \\
\text { Germany }\end{array}$ & Author & $\begin{array}{l}\text { Major role in the } \\
\text { acquisition of data }\end{array}$ \\
\hline $\begin{array}{l}\text { Andrea Kühn, } \\
\text { MD }\end{array}$ & $\begin{array}{l}\text { Klinik für Neurologie, Campus } \\
\text { Virchow, Charité- } \\
\text { Universitätsmedizin Berlin, } \\
\text { Germany }\end{array}$ & Author & $\begin{array}{l}\text { Major role in the } \\
\text { acquisition of data }\end{array}$ \\
\hline $\begin{array}{l}\text { Andreas } \\
\text { Kupsch, MD, } \\
\text { PhD }\end{array}$ & $\begin{array}{l}\text { Klinik für Neurologie, Campus } \\
\text { Virchow, } \\
\text { Charité-Universitätsmedizin } \\
\text { Berlin, Germany; Praxis Kupsch }\end{array}$ & Author & $\begin{array}{l}\text { Major role in the } \\
\text { acquisition of data }\end{array}$ \\
\hline $\begin{array}{l}\text { Gerd-H. } \\
\text { Schneider, } \\
\text { MD, PhD }\end{array}$ & $\begin{array}{l}\text { Klinik für Neurochirurgie, } \\
\text { Campus Virchow, } \\
\text { Charité-Universitätsmedizin } \\
\text { Berlin, Germany }\end{array}$ & Author & $\begin{array}{l}\text { Major role in the } \\
\text { acquisition of data }\end{array}$ \\
\hline $\begin{array}{l}\text { Eric } \\
\text { Seigneuret, } \\
\text { MD }\end{array}$ & $\begin{array}{l}\text { Service de Neurochirurgie, } \\
\text { Hôpital Michallon, Centre } \\
\text { Hospitalo-Universitaire, } \\
\text { Grenoble, France }\end{array}$ & Author & $\begin{array}{l}\text { Major role in the } \\
\text { acquisition of data }\end{array}$ \\
\hline $\begin{array}{l}\text { Valerie Fraix, } \\
\text { MD }\end{array}$ & $\begin{array}{l}\text { Grenoble Institut des } \\
\text { Neurosciences GIN, INSERM } \\
\text { U1216, Université Grenoble } \\
\text { Alpes; Service de Neurologie, } \\
\text { Hôpital Michallon, Centre } \\
\text { Hospitalo-Universitaire, } \\
\text { Grenoble, France }\end{array}$ & Author & $\begin{array}{l}\text { Major role in the } \\
\text { acquisition of data }\end{array}$ \\
\hline $\begin{array}{l}\text { Andrea } \\
\text { Kistner, MSc }\end{array}$ & $\begin{array}{l}\text { Grenoble Institut des } \\
\text { Neurosciences GIN; INSERM } \\
\text { U1216; Université Grenoble } \\
\text { Alpes, France }\end{array}$ & Author & $\begin{array}{l}\text { Major role in the } \\
\text { acquisition of data }\end{array}$ \\
\hline $\begin{array}{l}\text { P. Patrick } \\
\text { Chaynes, MD, } \\
\text { PhD }\end{array}$ & $\begin{array}{l}\text { Department of Neurosurgery, } \\
\text { University Hospital of Toulouse, } \\
\text { France }\end{array}$ & Author & $\begin{array}{l}\text { Major role in the } \\
\text { acquisition of data }\end{array}$ \\
\hline $\begin{array}{l}\text { Fabienne Ory- } \\
\text { Magne, MD }\end{array}$ & $\begin{array}{l}\text { Department of Neurology, } \\
\text { University Hospital of Toulouse; } \\
\text { ToNIC, Toulouse Neuroimaging } \\
\text { Center, University of Toulouse, } \\
\text { Inserm, UPS, France }\end{array}$ & Author & $\begin{array}{l}\text { Major role in the } \\
\text { acquisition of data }\end{array}$ \\
\hline $\begin{array}{l}\text { Christine } \\
\text { Brefel } \\
\text { Courbon, MD, } \\
\text { PhD }\end{array}$ & $\begin{array}{l}\text { Department of Neurology, } \\
\text { University Hospital of Toulouse; } \\
\text { Department of Neurology, } \\
\text { Department of Clinical } \\
\text { Pharmacology, University } \\
\text { Hospital of Toulouse; ToNIC, } \\
\text { Toulouse Neuroimaging Center, } \\
\text { University of Toulouse, Inserm, } \\
\text { UPS, France }\end{array}$ & Author & $\begin{array}{l}\text { Major role in the } \\
\text { acquisition of data }\end{array}$ \\
\hline
\end{tabular}


Appendix 1 (continued)

\begin{tabular}{|c|c|c|c|}
\hline Name & Location & Role & Contribution \\
\hline $\begin{array}{l}\text { Jan Vesper, } \\
\text { MD, PhD }\end{array}$ & $\begin{array}{l}\text { Department of Neurosurgery, } \\
\text { Universitätsklinikum } \\
\text { Düsseldorf, Germany }\end{array}$ & Author & $\begin{array}{l}\text { Major role in the } \\
\text { acquisition of data }\end{array}$ \\
\hline $\begin{array}{l}\text { Lars Wojtecki, } \\
\text { MD, PhD }\end{array}$ & $\begin{array}{l}\text { Institute of Clinical } \\
\text { Neuroscience \& Medical } \\
\text { Psychology and Department of } \\
\text { Neurology, Medical Faculty, } \\
\text { Heinrich-Heine-University } \\
\text { Düsseldorf, Germany }\end{array}$ & Author & $\begin{array}{l}\text { Major role in the } \\
\text { acquisition of data }\end{array}$ \\
\hline $\begin{array}{l}\text { Stéphane } \\
\text { Derrey, MD }\end{array}$ & $\begin{array}{l}\text { Department of Neurosurgery, } \\
\text { Rouen University Hospital and } \\
\text { University of Rouen, France }\end{array}$ & Author & $\begin{array}{l}\text { Major role in the } \\
\text { acquisition of data }\end{array}$ \\
\hline $\begin{array}{l}\text { David } \\
\text { Maltête, MD, } \\
\text { PhD }\end{array}$ & $\begin{array}{l}\text { Department of Neurology, } \\
\text { Rouen University Hospital and } \\
\text { University of Rouen; INSERM } \\
\text { U1239, Laboratory of Neuronal } \\
\text { and Neuroendocrine } \\
\text { Differentiation and } \\
\text { Communication, Mont-Saint- } \\
\text { Aignan, France }\end{array}$ & Author & $\begin{array}{l}\text { Major role in the } \\
\text { acquisition of data }\end{array}$ \\
\hline $\begin{array}{l}\text { Philippe } \\
\text { Damier, MD, } \\
\text { PhD }\end{array}$ & $\begin{array}{l}\text { Service de Neurologie, Hôpital } \\
\text { Laënnec, CHU Nantes, France }\end{array}$ & Author & $\begin{array}{l}\text { Major role in the } \\
\text { acquisition of data }\end{array}$ \\
\hline $\begin{array}{l}\text { Pascal } \\
\text { Derkinderen, } \\
\text { MD, PhD }\end{array}$ & $\begin{array}{l}\text { Service de Neurologie, Hôpital } \\
\text { Laënnec, CHU Nantes, France }\end{array}$ & Author & $\begin{array}{l}\text { Major role in the } \\
\text { acquisition of data }\end{array}$ \\
\hline $\begin{array}{l}\text { Friderike } \\
\text { Sixel-Döring, } \\
\text { MD }\end{array}$ & $\begin{array}{l}\text { Paracelsus-Elena-Klinik Kassel, } \\
\text { Germany }\end{array}$ & Author & $\begin{array}{l}\text { Major role in the } \\
\text { acquisition of data }\end{array}$ \\
\hline $\begin{array}{l}\text { Claudia } \\
\text { Trenkwalder, } \\
\text { MD, PhD }\end{array}$ & $\begin{array}{l}\text { Paracelsus-Elena-Klinik Kassel, } \\
\text { Germany; Department of } \\
\text { Neurosurgery, University } \\
\text { Medical Center Göttingen, } \\
\text { Germany }\end{array}$ & Author & $\begin{array}{l}\text { Major role in the } \\
\text { acquisition of data }\end{array}$ \\
\hline $\begin{array}{l}\text { Alireza } \\
\text { Gharabaghi, } \\
\text { MD, PhD }\end{array}$ & $\begin{array}{l}\text { Division of Functional and } \\
\text { Restorative Neurosurgery and } \\
\text { Centre for Integrative } \\
\text { Neuroscience, Tübingen, } \\
\text { Germany }\end{array}$ & Author & $\begin{array}{l}\text { Major role in the } \\
\text { acquisition of data }\end{array}$ \\
\hline $\begin{array}{l}\text { Tobias } \\
\text { Wächter, MD }\end{array}$ & $\begin{array}{l}\text { Abteilung für Neurologie, Reha- } \\
\text { Zentrum Bad Gögging, Passauer } \\
\text { Wolf, Germany }\end{array}$ & Author & $\begin{array}{l}\text { Major role in the } \\
\text { acquisition of data }\end{array}$ \\
\hline $\begin{array}{l}\text { Daniel Weiss, } \\
\text { MD, PhD }\end{array}$ & $\begin{array}{l}\text { Department for } \\
\text { Neurodegenerative Diseases } \\
\text { and Hertie Institute for Clinical } \\
\text { Brain Research, University of } \\
\text { Tübingen, Germany }\end{array}$ & Author & $\begin{array}{l}\text { Major role in the } \\
\text { acquisition of data }\end{array}$ \\
\hline $\begin{array}{l}\text { Marcus O. } \\
\text { Pinsker, MD, } \\
\text { PhD }\end{array}$ & $\begin{array}{l}\text { Division of Stereotactic and } \\
\text { Functional Neurosurgery, } \\
\text { University Medical Center } \\
\text { Freiburg, Germany }\end{array}$ & Author & $\begin{array}{l}\text { Major role in the } \\
\text { acquisition of data }\end{array}$ \\
\hline $\begin{array}{l}\text { Jean-Marie } \\
\text { Regis, MD, } \\
\text { PhD }\end{array}$ & $\begin{array}{l}\text { Department of Functional and } \\
\text { Stereotactic Neurosurgery and } \\
\text { Radiosurgery, Timone } \\
\text { University Hospital, INSERM, } \\
\text { Marseille, France }\end{array}$ & Author & $\begin{array}{l}\text { Major role in the } \\
\text { acquisition of data }\end{array}$ \\
\hline $\begin{array}{l}\text { Tatiana } \\
\text { Witjas, MD, } \\
\text { PhD }\end{array}$ & $\begin{array}{l}\text { Department of Neurology, } \\
\text { Timone University Hospital, } \\
\text { UMR 7289, CNRS Marseille, } \\
\text { France }\end{array}$ & Author & $\begin{array}{l}\text { Major role in the } \\
\text { acquisition of data }\end{array}$ \\
\hline $\begin{array}{l}\text { Stephane } \\
\text { Thobois, MD, } \\
\text { PhD }\end{array}$ & $\begin{array}{l}\text { Institut des Sciences Cognitives } \\
\text { Marc Jeannerod, CNRS, UMR } \\
\text { 5229, Université de Lyon; Centre } \\
\text { Expert Parkinson, Service de } \\
\text { Neurologie C, Hôpital } \\
\text { Neurologique Pierre } \\
\text { Wertheimer, Hospices Civils de } \\
\text { Lyon, Bron, France }\end{array}$ & Author & $\begin{array}{l}\text { Major role in the } \\
\text { acquisition of data }\end{array}$ \\
\hline
\end{tabular}

Appendix 1 (continued)

\begin{tabular}{|c|c|c|c|}
\hline Name & Location & Role & Contribution \\
\hline $\begin{array}{l}\text { Patrick } \\
\text { Mertens, MD, } \\
\text { PhD }\end{array}$ & $\begin{array}{l}\text { Department of Neurosurgery, } \\
\text { University Hospital of Neurology } \\
\text { and Neurosurgery, Hospices } \\
\text { Civils de Lyon, Université de } \\
\text { Lyon, France }\end{array}$ & Author & $\begin{array}{l}\text { Major role in the } \\
\text { acquisition of data }\end{array}$ \\
\hline $\begin{array}{l}\text { Karina } \\
\text { Knudsen, MD }\end{array}$ & $\begin{array}{l}\text { Neurologische Klinik im } \\
\text { Neurozentrum, Christian- } \\
\text { Albrechts-Universität Kiel, } \\
\text { Germany }\end{array}$ & Author & $\begin{array}{l}\text { Designed and } \\
\text { conceptualized } \\
\text { study, major role in } \\
\text { the acquisition of } \\
\text { data }\end{array}$ \\
\hline $\begin{array}{l}\text { Carmen } \\
\text { Schade- } \\
\text { Brittinger }\end{array}$ & $\begin{array}{l}\text { Coordinating Center for Clinical } \\
\text { trials of the Philipps University } \\
\text { of Marburg, Germany }\end{array}$ & Author & $\begin{array}{l}\text { Designed and } \\
\text { conceptualized } \\
\text { study, revised the } \\
\text { manuscript for } \\
\text { intellectual content }\end{array}$ \\
\hline $\begin{array}{l}\text { Jean-Luc } \\
\text { Houeto, MD, } \\
\text { PhD }\end{array}$ & $\begin{array}{l}\text { Department of Neurology, } \\
\text { INSERM-1402, Centre } \\
\text { Hospitalier Universitaire (CHU) } \\
\text { de Poitiers; University of } \\
\text { Poitiers, France }\end{array}$ & Author & $\begin{array}{l}\text { Designed and } \\
\text { conceptualized } \\
\text { study, major role in } \\
\text { the acquisition of } \\
\text { data, revised the } \\
\text { manuscript for } \\
\text { intellectual content }\end{array}$ \\
\hline $\begin{array}{l}\text { Yves Agid, MD, } \\
\text { PhD }\end{array}$ & $\begin{array}{l}\text { Département de Neurologie, } \\
\text { Centre d'Investigation Clinique } \\
\text { 1422, Hôpital Pitié-Salpêtrière, } \\
\text { Assistance Publique Hôpitaux } \\
\text { de Paris, Institut National de } \\
\text { Santé et en Recherche Médicale, } \\
\text { Institut du Cerveau et de la } \\
\text { Moelle Epinière, Paris, France }\end{array}$ & Author & $\begin{array}{l}\text { Design and } \\
\text { conceptualized } \\
\text { study }\end{array}$ \\
\hline $\begin{array}{l}\text { Marie } \\
\text { Vidailhet, MD, } \\
\text { PhD }\end{array}$ & $\begin{array}{l}\text { Département de Neurologie, } \\
\text { Centre d'Investigation Clinique } \\
\text { 1422, Hôpital Pitié-Salpêtrière, } \\
\text { Assistance Publique Hôpitaux } \\
\text { de Paris, Institut National de } \\
\text { Santé et en Recherche Médicale, } \\
\text { Institut du Cerveau et de la } \\
\text { Moelle Epinière, Paris, France }\end{array}$ & Author & $\begin{array}{l}\text { Designed and } \\
\text { conceptualized } \\
\text { study, revised the } \\
\text { manuscript for } \\
\text { intellectual content }\end{array}$ \\
\hline $\begin{array}{l}\text { Lars } \\
\text { Timmermann, } \\
\text { MD, PhD }\end{array}$ & $\begin{array}{l}\text { Department of Neurology, } \\
\text { University Hospital Cologne; } \\
\text { Universitätsklinikum Giessen } \\
\text { und Marburg, Marburg Campus, } \\
\text { Germany }\end{array}$ & Author & $\begin{array}{l}\text { Designed and } \\
\text { conceptualized } \\
\text { study, major role in } \\
\text { the acquisition of } \\
\text { data, revised the } \\
\text { manuscript for } \\
\text { intellectual content }\end{array}$ \\
\hline $\begin{array}{l}\text { Günther } \\
\text { Deuschl, MD, } \\
\text { PhD }\end{array}$ & $\begin{array}{l}\text { Neurologische Klinik im } \\
\text { Neurozentrum, Christian- } \\
\text { Albrechts-Universität Kiel, } \\
\text { Germany }\end{array}$ & Author & $\begin{array}{l}\text { Designed and } \\
\text { conceptualized } \\
\text { study, major role in } \\
\text { the acquisition of } \\
\text { data, drafted the } \\
\text { manuscript for } \\
\text { intellectual content }\end{array}$ \\
\hline
\end{tabular}


Appendix 2 Coinvestigators

\begin{tabular}{|c|c|c|c|}
\hline Name & Location & Role & Contribution \\
\hline $\begin{array}{l}\text { Virginie } \\
\text { Czernecki, } \\
\text { PhD }\end{array}$ & $\begin{array}{l}\text { Federation of } \\
\text { Neurology, } \\
\text { Hospital Pitié- } \\
\text { Salpêtrière, Paris, } \\
\text { France }\end{array}$ & $\begin{array}{l}\text { Site } \\
\text { investigator }\end{array}$ & Data collection \\
\hline $\begin{array}{l}\text { Helke } \\
\text { Hesekamp, } \\
\text { MD }\end{array}$ & $\begin{array}{l}\text { Federation of } \\
\text { Neurology, } \\
\text { Hospital Pitié- } \\
\text { Salpêtrière, Paris, } \\
\text { France }\end{array}$ & $\begin{array}{l}\text { Site } \\
\text { investigator }\end{array}$ & Data collection \\
\hline $\begin{array}{l}\text { Niklaus } \\
\text { Meier, MD }\end{array}$ & $\begin{array}{l}\text { Federation of } \\
\text { Neurology, } \\
\text { Hospital Pitié- } \\
\text { Salpêtrière, Paris, } \\
\text { France }\end{array}$ & $\begin{array}{l}\text { Site } \\
\text { investigator }\end{array}$ & Data collection \\
\hline $\begin{array}{l}\text { Velina } \\
\text { Negovanska, } \\
\text { PhD }\end{array}$ & $\begin{array}{l}\text { Federation of } \\
\text { Neurology, } \\
\text { Hospital Pitié- } \\
\text { Salpêtrière, Paris, } \\
\text { France }\end{array}$ & $\begin{array}{l}\text { Site } \\
\text { investigator }\end{array}$ & Data collection \\
\hline $\begin{array}{l}\text { Marie-Laure } \\
\text { Welter, MD, } \\
\text { PhD }\end{array}$ & $\begin{array}{l}\text { Federation of } \\
\text { Neurology, } \\
\text { Hospital Pitié- } \\
\text { Salpêtrière, Paris, } \\
\text { France }\end{array}$ & $\begin{array}{l}\text { Site } \\
\text { investigator }\end{array}$ & Data collection \\
\hline $\begin{array}{l}\text { Jean- } \\
\text { Christophe } \\
\text { Corvol, MD, } \\
\text { PhD }\end{array}$ & $\begin{array}{l}\text { Federation of } \\
\text { Neurology, } \\
\text { Hospital Pitié- } \\
\text { Salpêtrière, Paris, } \\
\text { France }\end{array}$ & $\begin{array}{l}\text { Site } \\
\text { investigator }\end{array}$ & Data collection \\
\hline $\begin{array}{l}\text { Philippe } \\
\text { Cornu, MD, } \\
\text { PhD }\end{array}$ & $\begin{array}{l}\text { Department of } \\
\text { Neurosurgery, } \\
\text { Hospital Pitié- } \\
\text { Salpêtrière, Paris, } \\
\text { France }\end{array}$ & $\begin{array}{l}\text { Site } \\
\text { investigator }\end{array}$ & $\begin{array}{l}\text { Contribution to } \\
\text { design and } \\
\text { conceptualization } \\
\text { of the study }\end{array}$ \\
\hline $\begin{array}{l}\text { Soledad } \\
\text { Navarro, MD }\end{array}$ & $\begin{array}{l}\text { Department of } \\
\text { Neurosurgery, } \\
\text { Hospital Pitié- } \\
\text { Salpêtrière, Paris, } \\
\text { France }\end{array}$ & $\begin{array}{l}\text { Site } \\
\text { investigator }\end{array}$ & Data collection \\
\hline $\begin{array}{l}\text { Bettina } \\
\text { Möller }\end{array}$ & $\begin{array}{l}\text { Department of } \\
\text { Neurology, } \\
\text { Christian- } \\
\text { Albrechts- } \\
\text { University, Kiel, } \\
\text { Germany }\end{array}$ & Psychologist & $\begin{array}{l}\text { Psychological } \\
\text { assessments, } \\
\text { data collection }\end{array}$ \\
\hline $\begin{array}{l}\text { Adelheid } \\
\text { Nebel }\end{array}$ & $\begin{array}{l}\text { Department of } \\
\text { Neurology, } \\
\text { Christian- } \\
\text { Albrechts- } \\
\text { University, Kiel, } \\
\text { Germany }\end{array}$ & $\begin{array}{l}\text { Site } \\
\text { investigator }\end{array}$ & Data collection \\
\hline $\begin{array}{l}\text { Karsten Witt, } \\
\text { MD, PhD }\end{array}$ & $\begin{array}{l}\text { Department of } \\
\text { Neurology, } \\
\text { Christian- } \\
\text { Albrechts- } \\
\text { University, Kiel, } \\
\text { Germany }\end{array}$ & $\begin{array}{l}\text { Site } \\
\text { investigator }\end{array}$ & Data collection \\
\hline $\begin{array}{l}\text { Jan Raethjen, } \\
\text { MD, PhD }\end{array}$ & $\begin{array}{l}\text { Department of } \\
\text { Neurology, } \\
\text { Christian- } \\
\text { Albrechts- } \\
\text { University, Kiel, } \\
\text { Germany }\end{array}$ & $\begin{array}{l}\text { Site } \\
\text { investigator }\end{array}$ & Data collection \\
\hline
\end{tabular}

Appendix 2 (continued)

\begin{tabular}{|c|c|c|c|}
\hline Name & Location & Role & Contribution \\
\hline $\begin{array}{l}\text { Maximilian } \\
\text { Mehdorn, } \\
\text { MD, PhD }\end{array}$ & $\begin{array}{l}\text { Department of } \\
\text { Neurosurgery, } \\
\text { Christian- } \\
\text { Albrechts- } \\
\text { University, Kiel, } \\
\text { Germany }\end{array}$ & $\begin{array}{l}\text { Director of } \\
\text { clinic } \\
\text { neurosurgery } \\
\text { in Kiel }\end{array}$ & Data collection \\
\hline $\begin{array}{l}\text { Ingo G. } \\
\text { Meister, MD, } \\
\text { PhD }\end{array}$ & $\begin{array}{l}\text { Department of } \\
\text { Psychiatry, } \\
\text { University } \\
\text { Hospital, Cologne, } \\
\text { Germany }\end{array}$ & $\begin{array}{l}\text { Site } \\
\text { investigator }\end{array}$ & Data collection \\
\hline $\begin{array}{l}\text { Jens Kuhn, } \\
\text { MD, PhD }\end{array}$ & $\begin{array}{l}\text { Department of } \\
\text { Psychiatry, } \\
\text { University } \\
\text { Hospital, Cologne, } \\
\text { Germany }\end{array}$ & $\begin{array}{l}\text { Site } \\
\text { investigator }\end{array}$ & Data collection \\
\hline $\begin{array}{l}\text { Josef Kessler, } \\
\text { MD, PhD }\end{array}$ & $\begin{array}{l}\text { Department of } \\
\text { Neurology, } \\
\text { University } \\
\text { Hospital, Cologne, } \\
\text { Germany }\end{array}$ & $\begin{array}{l}\text { Site } \\
\text { investigator }\end{array}$ & Data collection \\
\hline $\begin{array}{l}\text { Doreen } \\
\text { Gruber }\end{array}$ & $\begin{array}{l}\text { Department of } \\
\text { Neurology, } \\
\text { Charité, University } \\
\text { Berlin, Germany }\end{array}$ & $\begin{array}{l}\text { Site } \\
\text { investigator }\end{array}$ & Data collection \\
\hline $\begin{array}{l}\text { Katharina } \\
\text { Faust, MD, } \\
\text { PhD }\end{array}$ & $\begin{array}{l}\text { Department of } \\
\text { Neurology, } \\
\text { Charité, University } \\
\text { Berlin, Germany }\end{array}$ & $\begin{array}{l}\text { Site } \\
\text { investigator }\end{array}$ & Data collection \\
\hline $\begin{array}{l}\text { Stephan } \\
\text { Chabardes, } \\
\text { MD }\end{array}$ & $\begin{array}{l}\text { Department of } \\
\text { Neurosurgery, } \\
\text { Hospital Michallon, } \\
\text { University } \\
\text { Grenoble, France }\end{array}$ & $\begin{array}{l}\text { Site } \\
\text { investigator }\end{array}$ & Data collection \\
\hline $\begin{array}{l}\text { Pierre Pollak, } \\
\text { MD, PhD }\end{array}$ & $\begin{array}{l}\text { Department of } \\
\text { Neurology and } \\
\text { Psychiatry, } \\
\text { University } \\
\text { Grenoble, France }\end{array}$ & $\begin{array}{l}\text { Site } \\
\text { investigator }\end{array}$ & Data collection \\
\hline $\begin{array}{l}\text { Oliver Rascol, } \\
\text { MD, PhD }\end{array}$ & $\begin{array}{l}\text { Department of } \\
\text { Pharmacology, } \\
\text { University } \\
\text { Hospital, Toulouse, } \\
\text { France }\end{array}$ & $\begin{array}{l}\text { Site } \\
\text { investigator }\end{array}$ & Data collection \\
\hline $\begin{array}{l}\text { Christophe } \\
\text { Arbus }\end{array}$ & $\begin{array}{l}\text { Department of } \\
\text { Psychiatry, } \\
\text { University } \\
\text { Hospital, Toulouse, } \\
\text { France }\end{array}$ & $\begin{array}{l}\text { Site } \\
\text { investigator }\end{array}$ & Data collection \\
\hline Lola Danet & $\begin{array}{l}\text { Department of } \\
\text { Neurology, } \\
\text { University } \\
\text { Hospital, Toulouse, } \\
\text { France }\end{array}$ & $\begin{array}{l}\text { Site } \\
\text { investigator }\end{array}$ & Data collection \\
\hline $\begin{array}{l}\text { Romain } \\
\text { Lefaucheur }\end{array}$ & $\begin{array}{l}\text { Department of } \\
\text { Neurology, Rouen } \\
\text { University Hospital } \\
\text { and University of } \\
\text { Rouen, France }\end{array}$ & $\begin{array}{l}\text { Site } \\
\text { investigator }\end{array}$ & Data collection \\
\hline $\begin{array}{l}\text { Isabelle } \\
\text { Benatru }\end{array}$ & $\begin{array}{l}\text { Department of } \\
\text { Neurology } \\
\text { University of } \\
\text { Poitiers, France }\end{array}$ & $\begin{array}{l}\text { Site } \\
\text { investigator }\end{array}$ & Data collection \\
\hline
\end{tabular}


Appendix 2 (continued)

\begin{tabular}{|c|c|c|c|}
\hline Name & Location & Role & Contribution \\
\hline Olivier Colin & $\begin{array}{l}\text { Department of } \\
\text { Neurology } \\
\text { University of } \\
\text { Poitiers, France }\end{array}$ & $\begin{array}{l}\text { Site } \\
\text { investigator }\end{array}$ & Data collection \\
\hline $\begin{array}{l}\text { Solene } \\
\text { Ansquer }\end{array}$ & $\begin{array}{l}\text { Department of } \\
\text { Neurophysiology, } \\
\text { University of } \\
\text { Poitiers, France }\end{array}$ & $\begin{array}{l}\text { Site } \\
\text { investigator }\end{array}$ & Data collection \\
\hline $\begin{array}{l}\text { Stefan J. } \\
\text { Groiss }\end{array}$ & $\begin{array}{l}\text { Department of } \\
\text { Neurology, } \\
\text { Institute of Clinical } \\
\text { Neuroscience and } \\
\text { Medical } \\
\text { Psychology, } \\
\text { Heinrich-Heine- } \\
\text { University, } \\
\text { Düsseldorf, } \\
\text { Germany }\end{array}$ & $\begin{array}{l}\text { Site } \\
\text { investigator }\end{array}$ & Data collection \\
\hline $\begin{array}{l}\text { Saskia Elben, } \\
\text { PhD }\end{array}$ & $\begin{array}{l}\text { Department of } \\
\text { Neurology, } \\
\text { Institute of Clinical } \\
\text { Neuroscience and } \\
\text { Medical } \\
\text { Psychology, } \\
\text { Heinrich-Heine- } \\
\text { University, } \\
\text { Düsseldorf, } \\
\text { Germany }\end{array}$ & Psychologist & $\begin{array}{l}\text { Data collection, } \\
\text { psychological } \\
\text { testing }\end{array}$ \\
\hline $\begin{array}{l}\text { Christian } \\
\text { Hartmann, } \\
\text { MD, PhD }\end{array}$ & $\begin{array}{l}\text { Department of } \\
\text { Neurology, } \\
\text { Institute of Clinical } \\
\text { Neuroscience and } \\
\text { Medical } \\
\text { Psychology, } \\
\text { Heinrich-Heine- } \\
\text { University, } \\
\text { Düsseldorf, } \\
\text { Germany }\end{array}$ & $\begin{array}{l}\text { Site } \\
\text { investigator }\end{array}$ & Data collection \\
\hline $\begin{array}{l}\text { Martin } \\
\text { Südmeyer, } \\
\text { MD, PhD }\end{array}$ & $\begin{array}{l}\text { Department of } \\
\text { Neurology, } \\
\text { Institute of Clinical } \\
\text { Neuroscience and } \\
\text { Medical } \\
\text { Psychology, } \\
\text { Heinrich-Heine- } \\
\text { University, } \\
\text { Düsseldorf, } \\
\text { Germany }\end{array}$ & $\begin{array}{l}\text { Site } \\
\text { investigator }\end{array}$ & Data collection \\
\hline $\begin{array}{l}\text { Florian } \\
\text { Amtage, MD, } \\
\text { PhD }\end{array}$ & $\begin{array}{l}\text { Department of } \\
\text { Neurology, } \\
\text { University Hospital } \\
\text { Freiburg, Germany }\end{array}$ & $\begin{array}{l}\text { Site } \\
\text { investigator }\end{array}$ & Data collection \\
\hline $\begin{array}{l}\text { Rejko } \\
\text { Krueger, MD, } \\
\text { PhD }\end{array}$ & $\begin{array}{l}\text { Department of } \\
\text { Neurology, } \\
\text { University of } \\
\text { Tübingen, } \\
\text { Germany }\end{array}$ & $\begin{array}{l}\text { Site } \\
\text { investigator }\end{array}$ & $\begin{array}{l}\text { Data collection, } \\
\text { design and } \\
\text { conceptualization } \\
\text { of genetic } \\
\text { substudy }\end{array}$ \\
\hline $\begin{array}{l}\text { Severine } \\
\text { Ledily }\end{array}$ & $\begin{array}{l}\text { Department of } \\
\text { Neurology, } \\
\text { Hospital Laënnec, } \\
\text { University Nantes, } \\
\text { France }\end{array}$ & $\begin{array}{l}\text { Site } \\
\text { investigator }\end{array}$ & Data collection \\
\hline $\begin{array}{l}\text { Anne } \\
\text { Sauvaget }\end{array}$ & $\begin{array}{l}\text { Department of } \\
\text { Psychiatry, } \\
\text { Hospital Laënnec, } \\
\text { University Nantes, } \\
\text { France }\end{array}$ & $\begin{array}{l}\text { Site } \\
\text { investigator }\end{array}$ & Data collection \\
\hline
\end{tabular}

Appendix 2 (continued)

\begin{tabular}{|c|c|c|c|}
\hline Name & Location & Role & Contribution \\
\hline $\begin{array}{l}\text { Wenke } \\
\text { Schmidt }\end{array}$ & $\begin{array}{l}\text { Paracelsus-Elena- } \\
\text { Klinik, Kassel, } \\
\text { Germany }\end{array}$ & Psychologist & $\begin{array}{l}\text { Psychological } \\
\text { assessments, } \\
\text { data collection }\end{array}$ \\
\hline $\begin{array}{l}\text { Alexandro } \\
\text { Eusebio, MD, } \\
\text { PhD }\end{array}$ & $\begin{array}{l}\text { Department of } \\
\text { Neurology, } \\
\text { Hospital Timone, } \\
\text { Marseille, France }\end{array}$ & $\begin{array}{l}\text { Site } \\
\text { investigator }\end{array}$ & Data collection \\
\hline $\begin{array}{l}\text { Jean Philippe } \\
\text { Azulay, MD, } \\
\text { PhD }\end{array}$ & $\begin{array}{l}\text { Department of } \\
\text { Neurology, } \\
\text { Hospital Timone, } \\
\text { Marseille, France }\end{array}$ & $\begin{array}{l}\text { Site } \\
\text { investigator }\end{array}$ & Data collection \\
\hline $\begin{array}{l}\text { Gustavo } \\
\text { Polo, PhD }\end{array}$ & $\begin{array}{l}\text { Department of } \\
\text { Neurosurgery, } \\
\text { University Lyon 1, } \\
\text { France }\end{array}$ & $\begin{array}{l}\text { Site } \\
\text { investigator }\end{array}$ & Data collection \\
\hline $\begin{array}{l}\text { Serge Pinto, } \\
\text { PhD }\end{array}$ & $\begin{array}{l}\text { Department of } \\
\text { Laboratory Word } \\
\text { and Language, } \\
\text { University Aix- } \\
\text { Marseille, France }\end{array}$ & $\begin{array}{l}\text { Site } \\
\text { investigator }\end{array}$ & Data collection \\
\hline $\begin{array}{l}\text { Johannes } \\
\text { Levin, MD, } \\
\text { PhD }\end{array}$ & $\begin{array}{l}\text { Department of } \\
\text { Neurology, } \\
\text { University Munich- } \\
\text { Großhadern, } \\
\text { Munich, Germany }\end{array}$ & $\begin{array}{l}\text { Site } \\
\text { investigator }\end{array}$ & Data collection \\
\hline $\begin{array}{l}\text { Wolfgang H } \\
\text { Oertel, MD, } \\
\text { PhD }\end{array}$ & $\begin{array}{l}\text { Department of } \\
\text { Neurology } \\
\text { Philipps- } \\
\text { University, } \\
\text { Marburg, Germany }\end{array}$ & $\begin{array}{l}\text { BMT } \\
\text { committee }\end{array}$ & $\begin{array}{l}\text { Quality } \\
\text { management of } \\
\text { the BMT }\end{array}$ \\
\hline
\end{tabular}

\section{References}

1. Limousin P, Krack P, Pollak P, et al. Electrical stimulation of the subthalamic nucleus in advanced Parkinson's disease. N Engl J Med 1998;339:1105-1111.

2. Lagrange E, Krack P, Moro E, et al. Bilateral subthalamic nucleus stimulation improves health-related quality of life in PD. Neurology 2002;59:1976-1978.

3. Deuschl G, Schade-Brittinger C, Krack P, et al. A randomized trial of deep-brain stimulation for Parkinson's disease. N Engl J Med 2006;355:896-908.

4. Schupbach M, Gargiulo M, Welter ML, et al. Neurosurgery in Parkinson disease: a distressed mind in a repaired body? Neurology 2006;66:1811-1816.

5. Deuschl G, Schupbach M, Knudsen K, et al. Stimulation of the subthalamic nucleus at an earlier disease stage of Parkinson's disease: concept and standards of the EARLYSTIM-study. Parkinsonism Relat Disord 2013;19:56-61.

6. Schuepbach WM, Rau J, Knudsen K, et al. Neurostimulation for Parkinson's disease with early motor complications. N Engl J Med 2013;368:610-622.

7. Charles D, Konrad PE, Neimat JS, et al. Subthalamic nucleus deep brain stimulation in early stage Parkinson's disease. Parkinsonism Relat Disord 2014;20:731-737.

8. A controlled trial of rasagiline in early Parkinson disease: the TEMPO Study. Arch Neurol 2002;59:1937-1943.

9. Daniels C, Krack P, Volkmann J, et al. Is improvement in the quality of life after subthalamic nucleus stimulation in Parkinson's disease predictable? Mov Disord 2011;26:2516-2521.

10. Dafsari HS, Reker P, Silverdale M, et al. Subthalamic stimulation improves quality of life of patients aged 61 years or older with short duration of Parkinson's disease. Neuromodulation 2018;21:532-540.

11. Martinez-Martin P, Valldeoriola F, Tolosa E, et al. Bilateral subthalamic nucleus stimulation and quality of life in advanced Parkinson's disease. Mov Disord 2002;17:372-377.

12. Schrag A, Jahanshahi M, Quinn N. How does Parkinson's disease affect quality of life? A comparison with quality of life in the general population. Mov Disord 2000;15:1112-1118.

13. Soh SE, Morris ME, McGinley JL. Determinants of health-related quality of life in Parkinson's disease: a systematic review. Parkinsonism Relat Disord 2011;17:1-9.

14. Fereshtehnejad SM, Shafieesabet M, Farhadi F, et al. Heterogeneous determinants of quality of life in different phenotypes of Parkinson's disease. PLoS One 2015;10: e0137081.

15. Martinez-Martin P, Rodriguez-Blazquez C, Kurtis MM, Chaudhuri KR, Group NV. The impact of non-motor symptoms on health-related quality of life of patients with Parkinson's disease. Mov Disord 2011;26:399-406.

16. Charles PD, Van Blercom N, Krack P, et al. Predictors of effective bilateral subthalamic nucleus stimulation for PD. Neurology 2002;59:932-934. 
17. Kleiner-Fisman G, Herzog J, Fisman DN, et al. Subthalamic nucleus deep brain stimulation: summary and meta-analysis of outcomes. Mov Disord 2006;21(suppl 14):S290-S304.

18. Smeding HM, Speelman JD, Huizenga HM, Schuurman PR, Schmand B. Predictors of cognitive and psychosocial outcome after STN DBS in Parkinson's disease. J Neurol Neurosurg Psychiatry 2011;82:754-760.

19. Abboud H, Genc G, Thompson NR, et al. Predictors of functional and quality of life outcomes following deep brain stimulation surgery in Parkinson's disease patients: disease, patient, and surgical factors. Parkinsons Dis 2017;2017:5609163.

20. Witt K, Daniels C, Krack P, et al. Negative impact of borderline global cognitive scores on quality of life after subthalamic nucleus stimulation in Parkinson's disease. J Neurol Sci 2011;310:261-266.

21. Krack P, Batir A, Van Blercom N, et al. Five-year follow-up of bilateral stimulation of the subthalamic nucleus in advanced Parkinson's disease. N Engl J Med 2003; 349:1925-1934.

22. Weaver FM, Follett K, Stern M, et al. Bilateral deep brain stimulation vs best medical therapy for patients with advanced Parkinson disease: a randomized controlled trial. JAMA 2009;301:63-73.
23. Follett KA, Weaver FM, Stern M, et al. Pallidal versus subthalamic deep-brain stimulation for Parkinson's disease. N Engl J Med 2010;362:2077-2091.

24. Williams A, Gill S, Varma T, et al. Deep brain stimulation plus best medical therapy versus best medical therapy alone for advanced Parkinson's disease (PD SURG trial): a randomised, open-label trial. Lancet Neurol 2010;9:581-591.

25. Welter ML, Houeto JL, Tezenas du Montcel S, et al. Clinical predictive factors of subthalamic stimulation in Parkinson's disease. Brain 2002;125:575-583.

26. Krack P, Dowsey PL, Benabid AL, et al. Ineffective subthalamic nucleus stimulation in levodopa-resistant postischemic parkinsonism. Neurology 2000;54:2182-2184.

27. Russmann H, Ghika J, Villemure JG, et al. Subthalamic nucleus deep brain stimulation in Parkinson disease patients over age 70 years. Neurology 2004;63:1952-1954.

28. Deuschl G, Agid Y. Subthalamic neurostimulation for Parkinson's disease with early fluctuations: balancing the risks and benefits. Lancet Neurol 2013;12: 1025-1034.

29. Shulman LM, Gruber-Baldini AL, Anderson KE, Fishman PS, Reich SG, Weiner WJ. The clinically important difference on the Unified Parkinson's Disease Rating Scale. Arch Neurol 2010;67:64-70. 


\section{Neurology}

Quality of life predicts outcome of deep brain stimulation in early Parkinson disease

W.M. Michael Schuepbach, Lisa Tonder, Alfons Schnitzler, et al.

Neurology 2019;92;e1109-e1120 Published Online before print February 8, 2019

DOI 10.1212/WNL.0000000000007037

This information is current as of February 8, 2019

\section{Updated Information \&} Services

References

Citations

Subspecialty Collections

Errata

Permissions \& Licensing

Reprints including high resolution figures, can be found at: http://n.neurology.org/content/92/10/e1109.full

This article cites 29 articles, 6 of which you can access for free at: http://n.neurology.org/content/92/10/e1109.full\#ref-list-1

This article has been cited by 5 HighWire-hosted articles: http://n.neurology.org/content/92/10/e1109.full\#\#otherarticles

This article, along with others on similar topics, appears in the following collection(s):

\section{Parkinson's disease/Parkinsonism}

http://n.neurology.org/cgi/collection/parkinsons_disease_parkinsonism

An erratum has been published regarding this article. Please see next page or:

/content/92/24/1166.2.full.pdf

Information about reproducing this article in parts (figures,tables) or in its entirety can be found online at:

http://www.neurology.org/about/about_the_journal\#permissions

Information about ordering reprints can be found online:

http://n.neurology.org/subscribers/advertise

Neurology $\mathbb{B}$ is the official journal of the American Academy of Neurology. Published continuously since 1951, it is now a weekly with 48 issues per year. Copyright Copyright (C) 2019 The Author(s). Published by Wolters Kluwer Health, Inc. on behalf of the American Academy of Neurology.. All rights reserved. Print ISSN: 0028-3878. Online ISSN: 1526-632X.

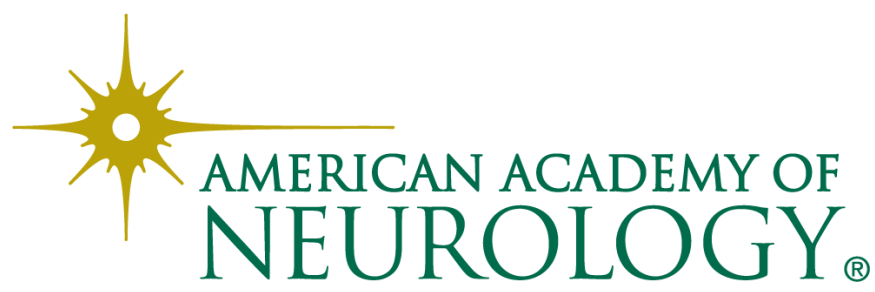




\section{Disputes \& Debates: Editors' Choice}

Steven Galetta, MD, FAAN, Section Editor

Editors' note: Practice guideline update recommendations summary: Disorders of consciousness: Report of the Guideline Development, Dissemination, and Implementation Subcommittee of the American Academy of Neurology; the American Congress of Rehabilitation Medicine; and the National Institute on Disability, Independent Living, and Rehabilitation Research

In their American Academy of Neurology (AAN) practice parameter, Giacino et al. provided a thorough review of the available evidence pertaining to the care of patients with impaired consciousness. The expert panel provided level of recommendations (LORs) regarding the discussion of long-term care needs, pain management strategies, and techniques for neuroprognostication in patients with disorders of consciousness. In response to these consensus recommendations, Phan et al. highlight 1 potential limitation of the LOR classification system that was used. Historically, the highest LOR (level A) was afforded only to recommendations based on 1 or more randomized clinical trials. However, this requirement was amended by the Institute of Medicine in 2011 as well as the 2011 AAN Clinical Guideline Practice Manual, as the authors emphasize in their response. After 2011, a level A recommendation was permitted as long as there was strong and consistent related evidence and inferences could be drawn. Therefore, a higher LOR could be assigned to recommendations with less explicit substantiation from large randomized clinical trials. By using this classification schema, some recommendations may be generalized to patients who are likely to benefit from such guidance.

James E. Siegler III, MD, and Steven Galetta, MD

Neurology ${ }^{\circledR}$ 2019;92:1163. doi:10.1212/WNL.0000000000007660

\section{Reader response: Practice guideline update recommendations summary: Disorders of consciousness: Report of the Guideline Development, Dissemination, and Implementation Subcommittee of the American Academy of Neurology; the American Congress of Rehabilitation Medicine; and the National Institute on Disability, Independent Living, and Rehabilitation Research}

Thanh G. Phan (Clayton, Australia), Udaya Seneviratne (Clayton, Australia), and Henry Ma (Clayton, Australia) Neurology ${ }^{\circledR}$ 2019;92:1163-1164. doi:10.1212/WNL.0000000000007668

We read with interest the disorders of consciousness guideline ${ }^{1}$ but found issues with the recommendations. Some of the recommendations are classified as level A (recommendations 3, 9, and 11). For example, "When prognosis is poor, long-term care must be discussed (level A)...." The references cited did not come from a randomized control trial. Typically, level A is based on one or more randomized control trial and is prefaced by a statement about the class of evidence. We cannot find references to any trials on which these recommendations were made. ${ }^{1,2}$ Can the authors reassess the use of the level of recommendation in this guideline? 
1. Giacino JT, Katz DI, Schiff ND, et al. Practice guideline update recommendations summary: disorders of consciousness: report of the Guideline Development, Dissemination, and Implementation Subcommittee of the American Academy of Neurology; the American Congress of Rehabilitation Medicine; and the National Institute on Disability, Independent Living, and Rehabilitation Research. Neurology 2018;91:450-460.

2. Giacino JT, Katz DI, Schiff ND, et al. Comprehensive systematic review update summary: disorders of consciousness: report of the Guideline Development, Dissemination, and Implementation Subcommittee of the American Academy of Neurology; the American Congress of Rehabilitation Medicine; and the National Institute on Disability, Independent Living, and Rehabilitation Research. Neurology 2018;91:461-470.

\title{
Author response: Practice guideline update recommendations summary: Disorders of consciousness: Report of the Guideline Development, Dissemination, and Implementation Subcommittee of the American Academy of Neurology; the American Congress of Rehabilitation Medicine; and the National Institute on Disability, Independent Living, and Rehabilitation Research
}

\begin{abstract}
Melissa J. Armstrong (Gainesville, FL), Joseph T. Giacino (Boston), Douglas I. Katz (Braintree, MA), Nicholas D. Schiff (New York), John Whyte (Elkins Park, PA), Eric J. Ashman (Kalamazoo, MI), Stephen Ashwal (Loma Linda, CA), Richard Barbano (Rochester, NY), Flora M. Hammond (Indianapolis), Steven Laureys (Liège, Belgium), Geoffrey S.F. Ling (Baltimore), Risa Nakase-Richardson (Tampa, FL), Ronald T. Seel (Richmond, VA), Stuart Yablon (Jackson, MS), Thomas S.D. Getchius (Washington, DC), and Gary S. Gronseth (Kansas City, KS) Neurology ${ }^{\circledR}$ 2019;92:1164. doi:10.1212/WNL.0000000000007669
\end{abstract}

American Academy of Neurology (AAN) guidelines comply with the AAN Institute Board-approved guideline methodology referenced within the systematic review/ guideline. ${ }^{1,2}$ Compliance is ensured by a methodologist working on each project and multiple rounds of AAN Guideline Development, Dissemination, and Implementation Subcommittee review. We believe that Phan et al. are referencing the 2004 recommendation methodology. ${ }^{3}$ The disorders of consciousness guideline used the 2011 AAN guideline manual, as amended, ${ }^{4}$ based on 2011 Institute of Medicine (IOM) standards for evidence-based guidelines. ${ }^{5}$ In this process, recommendations are based not only on a systematic review of the evidence but also on strongly related evidence, principles of care, and inferences. The level of obligation for each recommendation is determined by the strength of these premises and a risk-benefit assessment, with adjustments based on outcome importance, patient preference variability, feasibility/availability, and patient costs. Consensus is determined by a modified Delphi voting process in accordance with prespecified rules, as described in the systematic review. ${ }^{2}$ This IOM-compliant approach improves recommendation usability. The modified Delphi tables and the premise types for each recommendation rationale are available in the online appendices, NPub.org/m5ii8i ("rationale profiles" for recommendations 3, 9, and 11 are on pages 190, 204, and 206, respectively).

1. Giacino JT, Katz DI, Schiff ND, et al. Practice guideline update recommendations summary: disorders of consciousness: report of the Guideline Development, Dissemination, and Implementation Subcommittee of the American Academy of Neurology; the American Congress of Rehabilitation Medicine; and the National Institute on Disability, Independent Living, and Rehabilitation Research. Neurology 2018;91:450-460.

2. Giacino JT, Katz DI, Schiff ND, et al. Comprehensive systematic review update summary: disorders of consciousness: report of the Guideline Development, Dissemination, and Implementation Subcommittee of the American Academy of Neurology; the American Congress of Rehabilitation Medicine; and the National Institute on Disability, Independent Living, and Rehabilitation Research. Neurology 2018;91:461-470.

3. American Academy of Neurology. Clinical Practice Guideline Process Manual, 2004 ed. St. Paul, MN: American Academy of Neurology; 2004.

4. American Academy of Neurology. Clinical Practice Guideline Process Manual, 2011 ed. St. Paul: American Academy of Neurology; 2011.

5. Graham R, Mancher M, Miller Wolman D, Greenfield S, Steinberg E, editors. Clinical Practice Guidelines We Can Trust. Washington, DC: The National Academies Press; 2011. In: The National Academies of Sciences [online]. Available at: nationalacademies.org/hmd/ Reports/2011/Clinical-Practice-Guidelines-We-Can-Trust.aspx. Accessed October 12, 2018.

Copyright (c) 2019 American Academy of Neurology 


\section{Editors' note: Clinical Reasoning: A 54-year-old woman with confusion and visual disturbances}

Rossi et al. presented the unusual case of a 54-year-old woman with cirrhosis who developed oculomotor apraxia, optic ataxia, impaired smooth pursuit, and horizontal nystagmus in all directions of gaze. The neuroimaging and electrographic diagnosis was nonconvulsive status epilepticus resulting in Bálint syndrome. Dr. Pollak also suspects an epileptic origin of the horizontal, alternating nystagmus pattern, given the bilateral MRI and EEG findings. However, Dr. Pollack notes that a normal optokinetic nystagmus would be unusual during seizure activity. Rossi et al. attribute this to the fluctuating nature of the patient's condition and the intermittent epileptiform activity on EEG. Resolution of the cortical diffusion abnormalities on MRI would also have supported seizures as the cause of the patient's symptoms, as Dr. Pollak writes. Unfortunately, this could not be confirmed as the patient was lost to follow-up.

James E. Siegler III, MD, and Steven Galetta, MD

Neurology ${ }^{\circledR}$ 2019;92:1165. doi:10.1212/WNL.0000000000007671

\section{Reader response: Clinical Reasoning: A 54-year-old woman with confusion and visual disturbances}

Lea Pollak (Ness Ziona, Israel)

Neurology ${ }^{\circledR}$ 2019;92:1165. doi:10.1212/WNL.0000000000007670

In the Resident \& Fellow Clinical Reasoning paper by Rossi et al., ${ }^{1}$ the authors described an unusual case of Bálint syndrome caused by focal nonconvulsive status epilepticus in a patient with cirrhosis and hyponatremia. I am curious about the nature of the clinical finding: "... horizontal nystagmus in all directions including on primary gaze."

Horizontal nystagmus in all directions localizes to the brainstem/cerebellum; however, in this case, ${ }^{1}$ the lesions were parieto-occipital. Hyponatremia, if accompanied by hypomagnesemia, would cause a downbeat nystagmus. Could the nystagmus thus be an epileptic nystagmus of cortical origin? The bilaterality of the epileptic foci might explain the bilateral direction of the nystagmus. The authors describe an intermittent eye deviation on video during EEG recording; the mechanism is, therefore, probably due to epileptic alternative eye deviation with quick corrective saccades. It would be interesting to know the direction of the nystagmus, since this may elucidate whether the underlying activated mechanism of the eye deviations was saccadic or pursuit. Furthermore, the finding of a normal optokinetic nystagmus in Bálint syndrome and during seizures is mostly unusual. Also, can the authors please comment on the radiologic follow-up of this patient as the parieto-occipital T2 hyperintensities should resolve with time if attributed to seizure activity?

1. Rossi KC, Brandstadter R, Fields MC, Leong J, Shin S. Clinical Reasoning: a 54-year-old woman with confusion and visual disturbances. Neurology 2018;91:363-367. 


\section{Author response: Clinical Reasoning: A 54-year-old woman with confusion and visual disturbances}

Kyle C. Rossi (New York), Rachel Brandstadter (New York), Madeline C. Fields (New York), and

Susan Shin (New York)

Neurology ${ }^{\circledR}$ 2019;92:1166. doi:10.1212/WNL.0000000000007672

We thank Dr. Pollak for the thoughtful comments on our article. ${ }^{1}$ The nature of the nystagmus was variable over the clinical course. Our earliest notes described direction-changing horizontal gaze-evoked nystagmus on left and right end gaze and primary gaze. The mechanism of epileptic nystagmus is poorly understood with most available literature being from case reports, often reporting the fast phase of nystagmus away from the seizure focus. ${ }^{2-4}$ Here, the bilateral foci could explain the direction changing nature of the nystagmus. Of note, the case was confounded by metabolic derangements, potentially contributing to brainstem dysfunction and eye movement abnormalities. Although epileptic nystagmus is possible, it is difficult to conclude with certainty.

The intact optokinetic nystagmus (OKN) reflex could be related to the fluctuating nature of the symptoms given an epileptic origin as opposed to a fixed structural origin. Additionally, Baloh et al. ${ }^{5}$ reported on the structural pathways involved in the $\mathrm{OKN}$ reflex, suggesting a complicated 2-pathway mechanism and showing that many parietal lesions do not obliterate all parts of the OKN response uniformly.

Regarding follow-up imaging, the patient was unfortunately lost to follow-up from a neurology perspective; the plan for follow-up imaging was not completed at our institution.

1. Rossi KC, Brandstadter R, Fields MC, Leong J, Shin S. Clinical Reasoning: a 54-year-old woman with confusion and visual disturbances. Neurology 2018;91:363-367.

2. Lee SU, Suh HI, Choi JY, et al. Epileptic nystagmus: a case report and systematic review. Epilepsy Behav Case Rep 2014;2:156-160.

3. Ma Y, Wang J, Li D, Lang S. Two types of isolated epileptic nystagmus: case report. Int J Clin Exp Med 2015;8:13500-13507.

4. Bhai S, Malik AN, Bakhadirov K, Prasad S. Alternating ictal and postictal nystagmus. Neurol Clin Pract 2014;4:522-523.

5. Baloh RW, Yee RD, Honrubia V. Optokinetic nystagmus and parietal lobe lesions. Ann Neurol 1980;7:269-276.

Copyright @ 2019 American Academy of Neurology

CORRECTION

\section{Quality of life predicts outcome of deep brain stimulation in early Parkinson disease}

Neurology ${ }^{\circledR}$ 2019;92:1166. doi:10.1212/WNL.0000000000007420

In the article "Quality of life predicts outcome of deep brain stimulation in early Parkinson disease" by Schuepbach et al., ${ }^{1}$ published online ahead of print on February 8, 2019, Dr. Hälbig's name should have included a middle initial: Thomas D. Hälbig. The corrected name appears in the March 5 issue. The editorial office regrets the error.

\section{Reference}

1. Schuepbach WMM, Tonder L, Schnitzler A, et al. Quality of life predicts outcome of deep brain stimulation in early Parkinson disease. Neurology 2019;92:e1109-e1120. 